Article

\title{
Simulation and Experimental Studies of a Multi-Tubular Floating Sea Wave Damper
}

\author{
Leszek Chybowski ${ }^{(D)}$, Zenon Grządziel and Katarzyna Gawdzińska * (iD \\ Faculty of Marine Engineering, Maritime University of Szczecin, 70-500 Szczecin, Poland; \\ 1.chybowski@am.szczecin.pl (L.C.); z.grzadziel@am.szczecin.pl (Z.G.) \\ * Correspondence: k.gawdzinska@am.szczecin.pl; Tel.: +48-914-809-941
}

Received: 26 March 2018; Accepted: 11 April 2018; Published: 20 April 2018

check for updates

\begin{abstract}
This article explores the issue of shore protection from sea waves and has presented the main methods used for coastal protection. It discusses the construction and operation of the multi-tubular floating sea wave damper that has been developed at the Maritime University of Szczecin by Professor Bolesław Kuźniewski. This paper presents the results of the research project aimed at creating and examining a prototype of the device. The research aimed to confirm the two hypotheses: "the largest damping force should occur when the damping units are placed at an optimal distance equal to half the length of the wave to be damped" and "a compensation of the horizontal forces caused by the rippling of water should occur in the damping device". Simulation studies of the behaviour of the device's buoyancy elements when floating on waves were performed using the ANSYS AQWAWB and AQWA software. The buoyancy components were modelled as TUBE elements with a diameter of $0.11 \mathrm{~m}$ and a length of $1.5 \mathrm{~m}$ and as triangular and square surface elements. The results of the experimental research and the computer simulation of the operation of the prototype device have also been presented. The external conditions adopted corresponded to the frequency of a wave equal to $0.807 \mathrm{~Hz}$ and to the wave height in front of the device which was equal to $0.1 \mathrm{~m}$. Experimental studies were conducted in an auxiliary model basin with dimensions of $60 \mathrm{~m} \times 7 \mathrm{~m} \times 3.12 \mathrm{~m}$ at the Ship Hydromechanics Division, Ship Design and Research Centre (CTO S. A.) in Gdańsk (Poland). The study recorded the distribution of the vertical and horizontal forces acting on the prototype device as well as the wave height both in front of and behind the device. Both hypotheses were proven. Simulation and experimental studies have been summarised. A proposal for future works has also been presented.
\end{abstract}

Keywords: sea waves; damping; shore protection; model basin; load simulation; multi-tubular floating damper; Kuźniewski's damper

\section{Introduction}

Effective protection of the sea shore remains a valid but still unsolved social issue that forms part of the responsibilities of any public authority. The coastal area is a space of human expansion which includes the majority of hydrotechnical facilities. Furthermore, it is estimated that more than $60 \%$ of the world's population inhabit coastal areas [1]. These areas are directly related to many fields of human activity, such as industry, trade, agriculture, fishing and tourism. As a rule, hydrotechnical facilities are structures that are subjected to complex mechanical loadings [2-8], among which of primary importance are the hydrotechnical forces associated with water movement $[9,10]$. The most important factors that cause water movement in coastal zones are surface waves and wave-driven currents [11-13]. Dynamic phenomena occurring in coastal zones [14], including wind-driven sea waves which are a major cause, contribute to coastal erosion and abrasion [15]. Figure 1 shows an overview map of the impact of erosion processes on European sea shores. Particularly great coastal 
damage can be observed in Belgium, Denmark, Estonia, France, Spain and Italy. Interesting case studies regarding Mediterranean islands can be found in references [11,12,16].

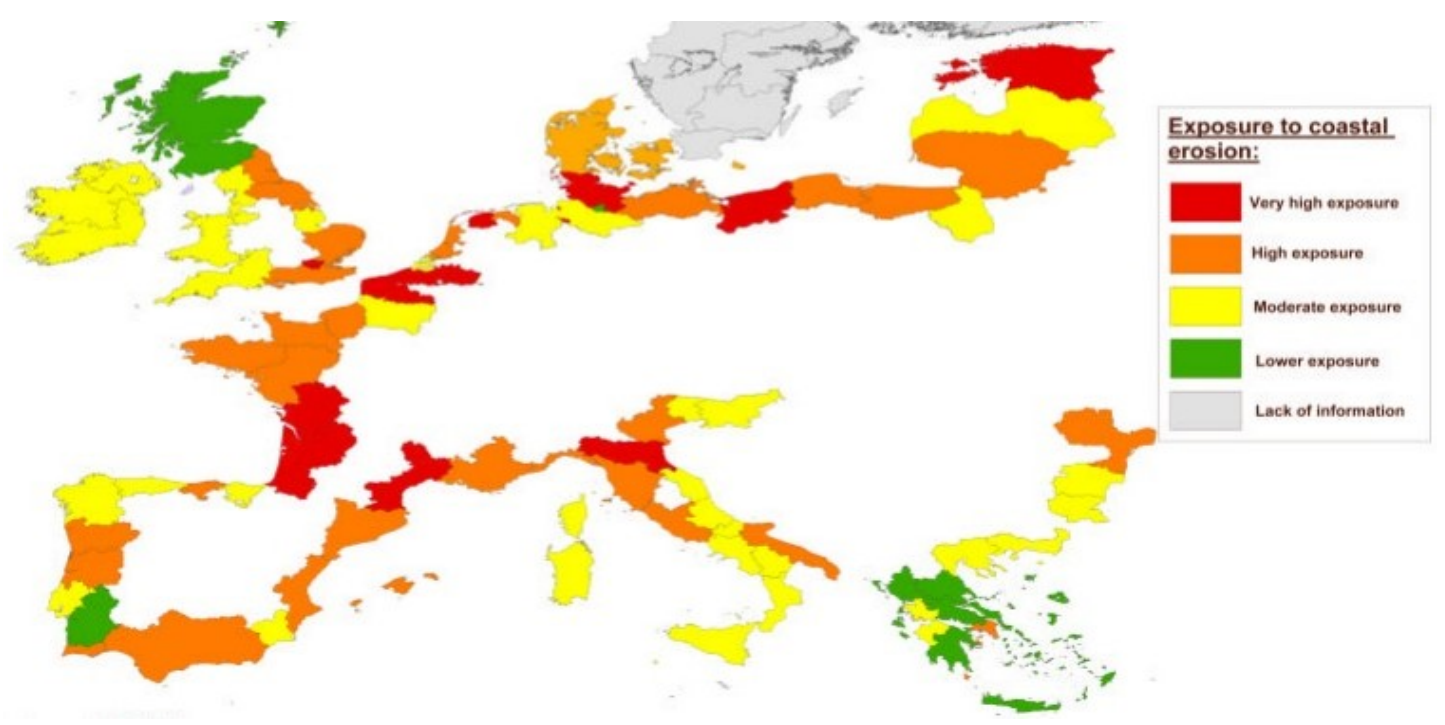

Figure 1. Exposure to coastal erosion in Europe [17].

For example, the Polish sea annually claims about 50 hectares of land which have a total value of 500 million zlotys. The worst situation is on the western coast, on the Hel Peninsula and on the Vistula Spit [1]. There are areas where coastal regression exceeds one meter per year. Approximately $60 \%$ to $70 \%$ of the Polish coastline is exposed to erosion caused by wave movement. Every year, the country's territory is reduced by about $340,000 \mathrm{~m}^{2}$ [18]. In recent decades, more than $70 \%$ of the Polish coast has been affected by erosive processes. The average annual rate of coastline recession in the years from 1975 to 1983 was $0.9 \mathrm{~m}$ /year. Furthermore, it is important to realise that a coastline recession at the rate of only $0.10 \mathrm{~m}$ per year means a loss of land area equal to about $37,000 \mathrm{~m}^{2}$ per year. There are a number of methods of coastal protection which vary in efficiency, implementation and operation costs and level of environmental interference [19-22]. A brief overview of the basic methods is presented in Figure 2.

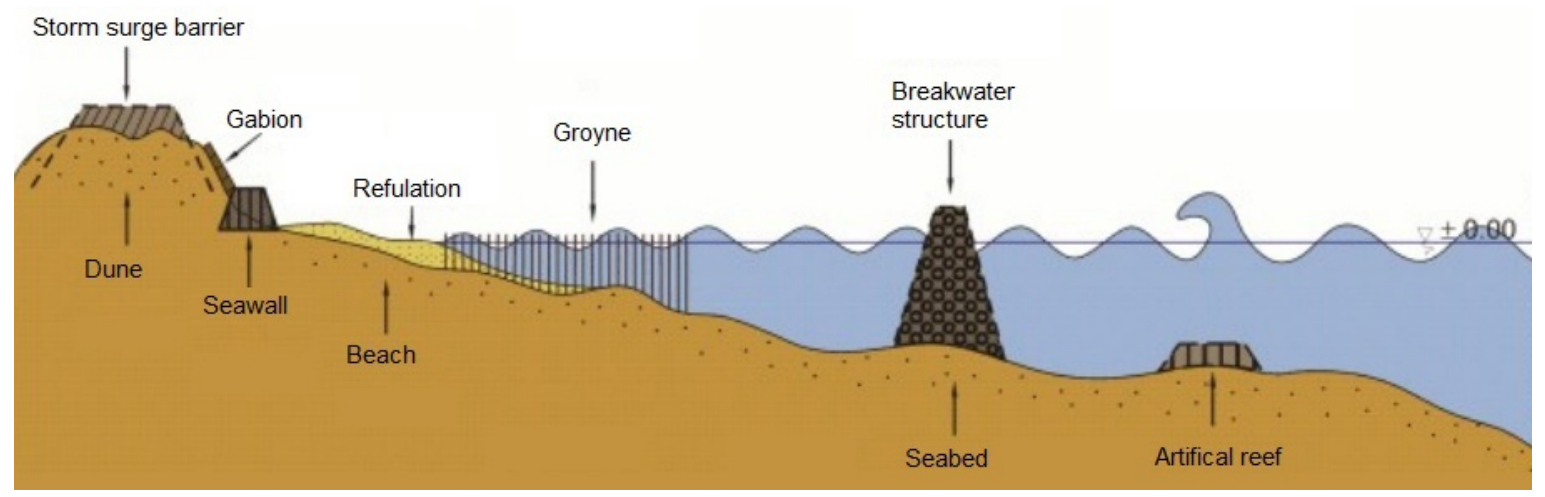

Figure 2. Technical methods of shore protection [22].

The following methods are among the most popular:

$>$ Breakwater-this consists of concrete, stone or prefabricated structures placed parallel or at an angle to the shoreline. Figure 3 shows example breakwaters made of patented prefabricates of 
various types. One disadvantage to this solution is the deepening of the water basin directly in front of the structure from the side of the open sea, huge implementation cost and limits to water exchange between the sea and the area being protected.

$>$ Components installed on the sea bed, below the water surface-barrages, artificial reefs. The drawback to these kinds of structures is the deepening of the water basin directly in front of the structure and the need for maintenance and systematic monitoring of its technical condition.

$>$ Structures placed in the beach area-plants, fences, brushwood, geotextiles and geosynthetic materials. The disadvantage of this type of solution is the extent of intervention in the natural ecosystem of the dunes.

> Gabion-concrete, soil and stone or prefabricated structure located on the slopes of dunes or cliffs. The disadvantage of this is sublittoral deepening and the slow erosion of its outskirts.

> Groyne-wooden posts laid perpendicularly to the shoreline reaching 100-200 m into the sea. A disadvantage of this solution is low efficiency in sediment-poor areas, deepening of the sea bottom in front of the structure, formation of erosional bays and the need for periodic maintenance.

$>$ Refulation - a method which consists of collecting sandy material from the sea bottom by dredging and placing it on the shoreline by means of pipelines. Its main drawback is the need for periodic repetition of the process and the extent of environmental intervention at the place of collection of material.

$>$ Storm surge barriers-the purpose these structures serve is the protection of areas located close to sea level. Their disadvantages are high maintenance costs and the need to provide large amounts of construction material.

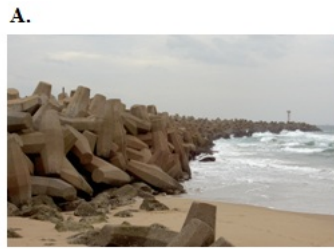

D.

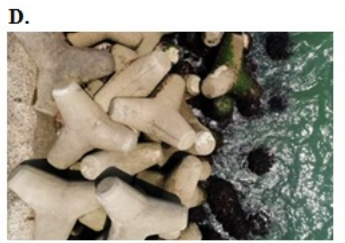

G.

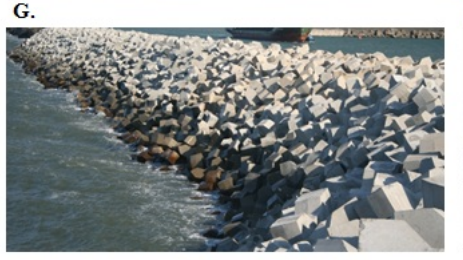

B.

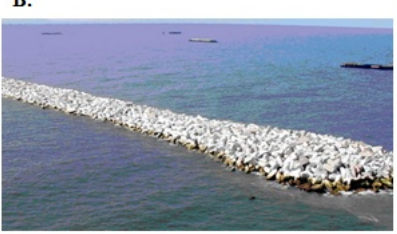

E.

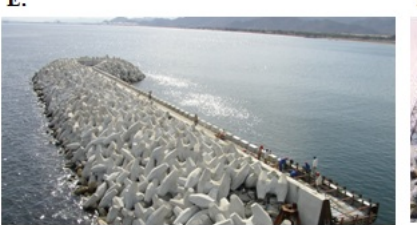

H.

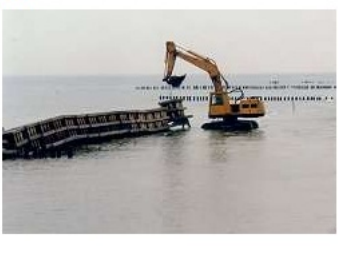

C.

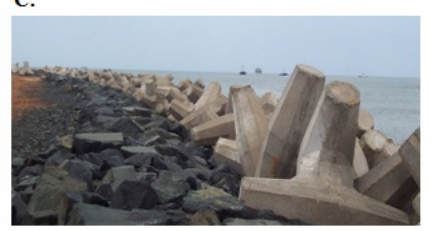

F.

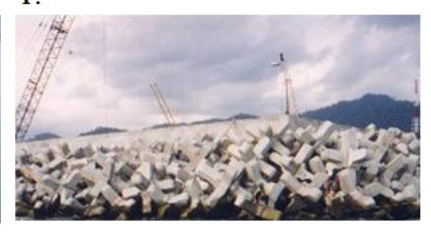

Figure 3. Breakwaters made of prefabricates of various types: (A) Dolosse, (B) Accropode, (C) KOLOS, (D) Tetrapod, (E) Core-loc, (F) A-Jack, (G) Xbloc, (H) Waveblock [19].

The presented overview of the technical solutions has demonstrated that their huge disadvantage lies is the fact that in order to protect the coastal area they have to be permanent engineering structures. This fact is the cause of their high expense, adverse impact on the natural appearance of the sea shore, disruption of the balance in adjacent ecosystems, and reduction of the recreational value of coastal areas. Furthermore, another drawback of such solutions is that the sea waves often direct their destructive energy towards locations close to the protected area. A possible solution to these drawbacks is the use of multi-tubular floating dampers presented in [23] (pp. 14-15). 


\section{Results-Kuźniewski's Damper}

This invention was developed by Professor Bolesław Kuźniewski in 2007 at the Maritime University in Szczecin. The solution was granted the patent PL 210,447 [24] by the Polish Patent Office. The object of the invention was a method of shore protection against sea waves during storms and a sea wave damping assembly. Elements of the prototype device are shown in Figure 4.

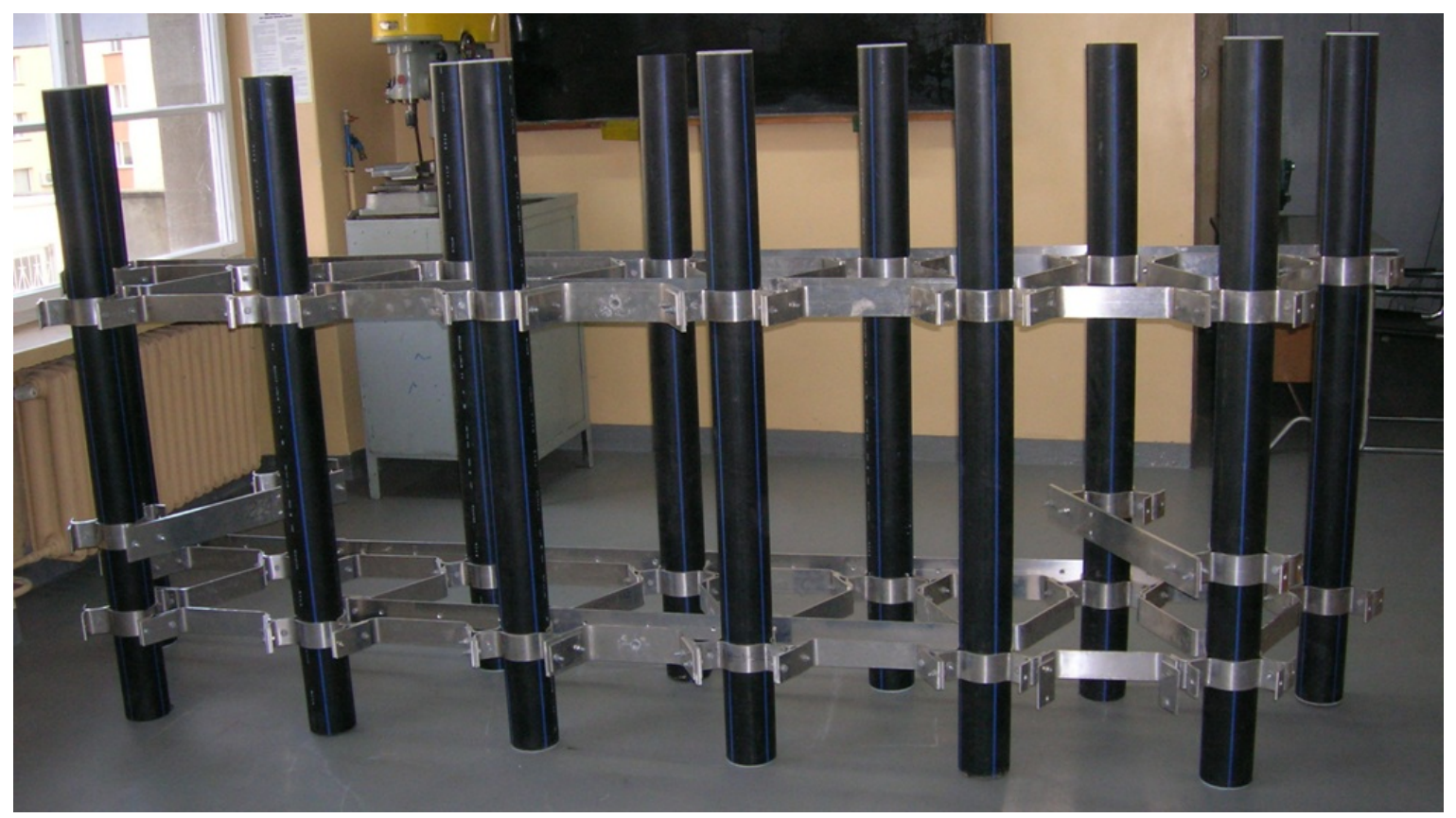

Figure 4. Components of the Kuźniewski's damper prototype.

In accordance with the patent claim, the invention is a method of coastal protection consisting of placing in the way of sea waves beneath the rippling water at least one unit of the sea wave damper, composed of vertical tubular floating elements, and locating it behind the wave transformation line (breaking line) and at an economically optimal distance from the shoreline. The upper edges of the damping unit are underneath the surface of the water, while its lower edges are located at a distance from the bottom of the sea. The unit is attached to anchoring elements resting on the seabed by means of at least two tie rods. One of the benefits of the invention is that the unit's weight is less than its buoyancy.

The invention is visualised in Figure 5. The sea wave damping unit (1) contains thirty-four vertical elements (8) arranged in five rows. The vertical element (8) is a tube closed at both ends which constitutes a natural float with a specific buoyancy force. On each vertical tubular element (8), in its top and bottom part, there is a clamp (7) which is a three-sectional bracket connected by means of bolts. Each of the three elements of the bracket is equipped with a clamp to which the cut-off top of the rigid spacer (9) is attached using two bolts. The spacer is a flat bar in the form of a triangular truss with cut-off tops and a triangle inscribed within it. The spacers (9) combine the vertical elements (8) in their upper and lower parts, forming two rigid trusses in two planes. In one row of the vertical tubular elements (8) three top ends of the rods (6) are attached to the bottom of the clamps (7), and each of the lower ends of the rods (6) are fastened to the anchoring element (5) located on the seabed (4). Figure $5 \mathrm{~B}$ present a top view of the device. The width ' $\mathrm{S}$ ' of the damping unit (1) is $4 \mathrm{~m}$, and its length is $8 \mathrm{~m}$. The height of the vertical elements (8) is $4 \mathrm{~m}$. The device may also contain thirty vertical elements arranged in five rows of six elements [24]. 

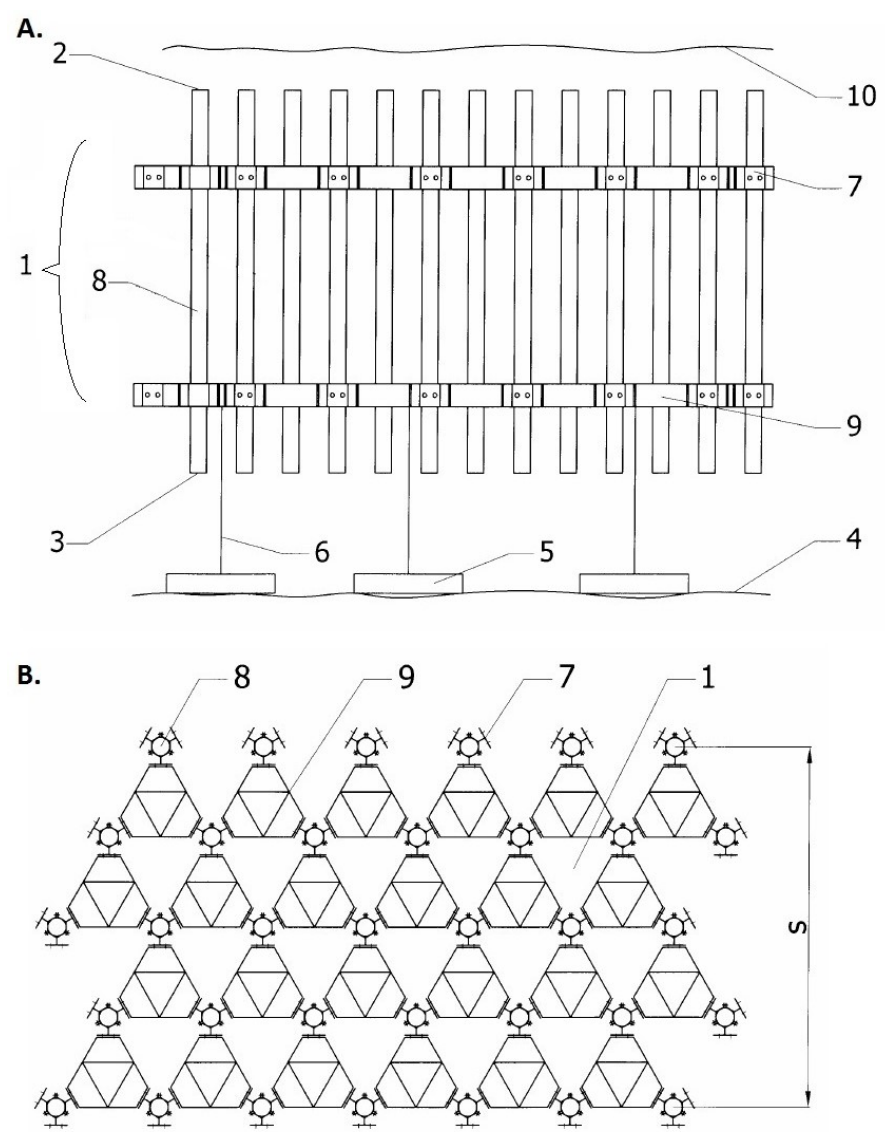

Figure 5. Views of the sea wave damping unit located in the water column [24]; (A) Frontal view;

(B) Top view (description in the text).

Figure 6 presents a system for coastal protection consisting of three damping units (1) arranged in a row behind the wave transformation line (breaking line) (12). The system can protect $30 \mathrm{~m}$ of the shoreline (11). Each damping unit (1) is installed within the water column in such a way that the upper edge (2) is, according to general recommendations, placed $0.5 \mathrm{~m}$ from the mean water level (10) and the lower edge (3) is located $1 \mathrm{~m}$ above the seabed. The sea wave damping units are located along the shoreline in at least one row.

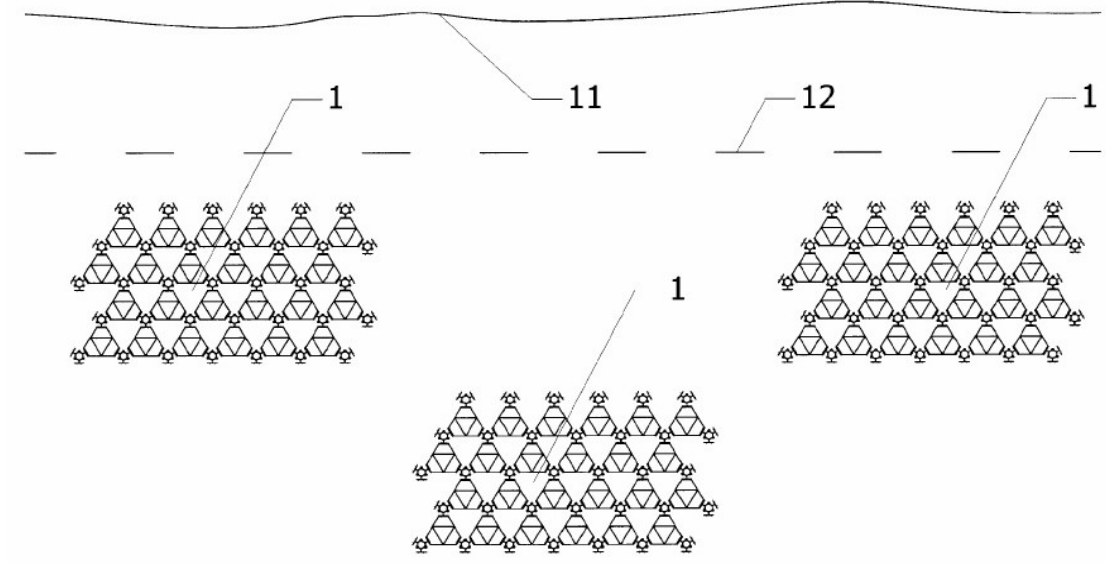

Figure 6. The coastal protection system consisting of three damping units in a row [24] (description in the text). 
The method for sea wave damping featured by the device allows for the dissipation of the energy of sea waves during a storm and thus protects the shoreline. The height of the vertical element ranges from 0.2 to 1.0 of the dominant wave length. The damping units are to be used for the protection of coastlines against storm wave damage by means of damping the energy of the sea wave already in the water and at a certain distance from the shoreline.

Installing the damping units at a distance equal to half of the wave length leads to the fact that horizontal forces caused by movement of the rippling water by the first unit are directed contrary to the horizontal forces by the second unit and thus the forces are mutually compensating [1]. A diagram of the damping device consisting of two identical units has been presented in Figure 7, where size $\mathrm{A}$ is the width of the damping device, size B is the distance between the units, and size $C$ is the width of the units which may not exceed half of the wave length.

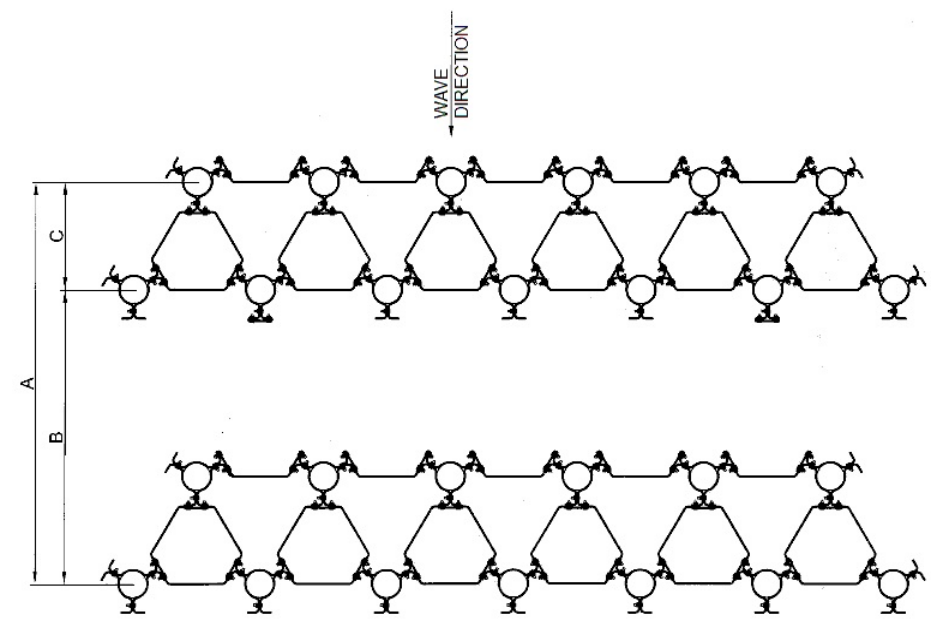

Figure 7. Diagram of a damping device consisting of two units as seen from the top to down view [1] (description in the text).

With a constant unit width, the greatest damping effect occurs when the spacing between the units is equal to half the wave length. The increase in the unit's width enhances damping efficiency and simultaneously increases the width of the device. It follows that the greatest attenuation effect can be achieved when the width of the damping device is equal to the wave length, which has been specified in the patent application.

Kuźniewski's damper was subjected to experimental tests conducted in a $60 \mathrm{~m} \times 7 \mathrm{~m} \times 3.12 \mathrm{~m}$ model basin (auxiliary pool) at the Ship Hydromechanics Division, Ship Design and Research Centre (CTO S. A.) in Gdańsk (Poland). Figure 8 showns the already immersed device in the course of the tests.
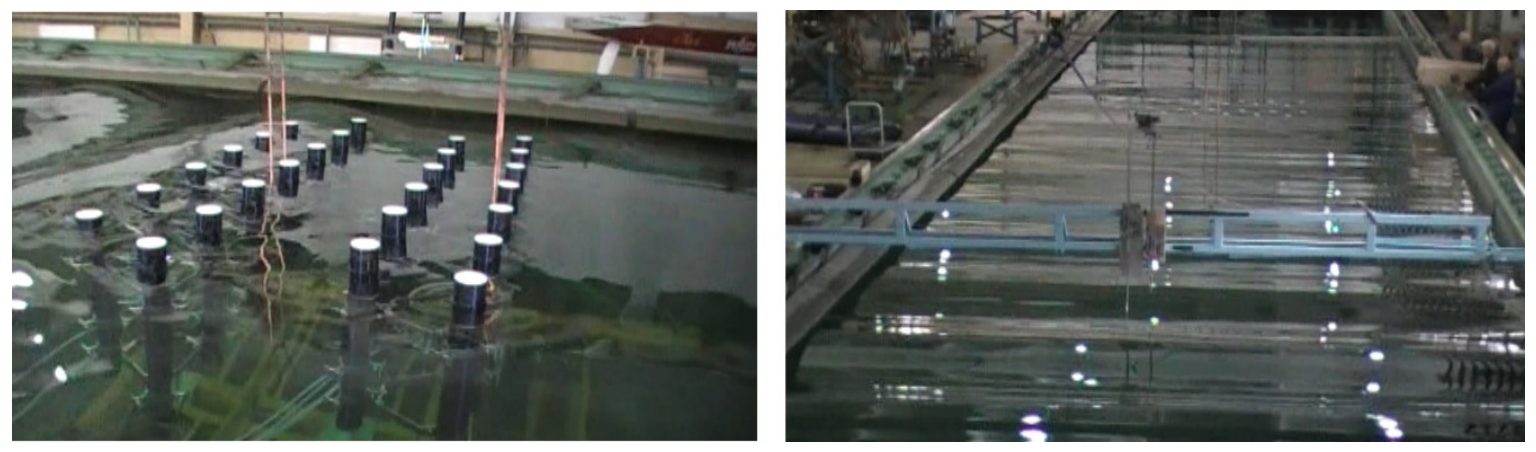

Figure 8. The damping device in the course of tests in the model basin of the Ship Hydromechanics Division, Ship Design and Research Centre (CTO S. A.) in Gdańsk. 
A simulation and experimental plan was developed for the damping device prototype to determine its performance and parameters and to confirm the following hypotheses:

$>$ The largest damping force should occur when the damping units are placed at an optimal distance equal to half the length of the wave to be damped.

$>$ compensation of the horizontal forces caused by the rippling of water should occur in the damping device.

The examination was carried out to measure both the vertical and horizontal forces caused by the rippling water and, subsequently, to analyse the results of the measurements of the forces in order to perform:

$>$ a harmonic analysis of the horizontal forces acting on the damping units;

$>$ a harmonic analysis of the waves that trigger these forces;

$>$ an analysis of the compensation of the horizontal forces.

\section{Studies and Discussion}

\subsection{Simulation Studies}

The tested wave damping device was designed in such a way that the distance between the two damping segments was $1.2 \mathrm{~m}$, which corresponds to half the wave length. The length of the simulated wave has to be equal to $2.4 \mathrm{~m}$ with amplitude of $0.05 \mathrm{~m}$. Such waves were obtained at the auxiliary model basin at the Ship Design and Research Centre in Gdańsk. The speed $c$ of the wave propagation depends not only on the length $\lambda$ of the waves, but also on the depth $h$ of the water [1]. In the general case, if: $\frac{\lambda}{h}<2$ then wave speed, $c$, is equal to:

$$
c=\sqrt{\frac{g}{\kappa} \tanh (\kappa \cdot g)}
$$

where: $\mathcal{\kappa}=\frac{4 \pi^{2}}{T^{2} g}$ is the wave number, $g=9806 \mathrm{~m} / \mathrm{s}^{2}$ is acceleration due to gravity, $T$ is the wave period and tanh is the hyperbolic tangent.

The dependence of the main parameters of the wave from its period for the deep water area is given in Table 1.

Table 1. The values of wave number $\kappa$, wave speed $c$, wave length $\lambda$ and wave frequency $f$ as a function of the wave period $T$, for deep water waves.

\begin{tabular}{ccccc}
\hline $\mathbf{T}$ & $\kappa=\frac{4 \pi^{2}}{T^{2} g}$ & $\boldsymbol{c}=\sqrt{\frac{g}{\kappa} \tan \mathbf{h}(\kappa \cdot g)}$ & $\lambda=c \boldsymbol{T}$ & $f=\frac{1}{T}$ \\
\hline$[\mathrm{s}]$ & {$[\mathrm{rad} / \mathrm{m}]$} & {$[\mathrm{m} / \mathrm{s}]$} & {$[\mathrm{m}]$} & {$[\mathrm{Hz}]$} \\
\hline 0.8866 & 5.1217 & 1.3837 & 1.2268 & 1.1279 \\
1.2399 & 2.6187 & 1.9351 & 2.3993 & 0.8065 \\
1.5185 & 1.7460 & 2.3699 & 3.5987 & 0.6585 \\
1.7336 & 1.3396 & 2.7056 & 4.6904 & 0.5768 \\
\hline
\end{tabular}

Due to the small amplitude of the examined waves $(0.05 \mathrm{~m})$ relative to the depth $h(3 \mathrm{~m})$ of the water, the speed $c$ and wave length $\lambda$ can also be expressed using the period $T$ :

$$
c=\frac{g T}{2 \pi}
$$

Based on Table 1 and the values obtained from Equation (2), it can be seen that the calculations for $c, l$ and $f$ for the deep water waves also showed the same values for small amplitude waves. For the 
tested wave length $l=2.4 \mathrm{~m}$, wave period $T=1.2399 \mathrm{~s}$ (frequency $f=0.807 \mathrm{~Hz}$ ) and phase speed of wave $c=1.9359 \mathrm{~m} / \mathrm{s}$.

\subsubsection{Load Simulation of One Buoyancy Element}

A single buoyancy element was made from PE HD 100 polyethylene tube for water systems, with an outer diameter of $f_{\mathrm{z}}=0.11 \mathrm{~m}$ and wall thickness $\mathrm{g}=0.0066 \mathrm{~m}$. The total length of one tube $\mathrm{L}=1.5 \mathrm{~m}$. PE HD 100 polyethylene has a density of $980 \mathrm{~kg} / \mathrm{m}^{3}$, slightly less than the density of water. The other parameters with regard to a single tube, which are required in the load simulation process, took the following values:

$>$ tube mass $\mathrm{m}=3.139 \mathrm{~kg}$

$>$ moments of inertia: $\mathrm{J}_{\mathrm{xx}}=\mathrm{J}_{\mathrm{yy}}=0.5885 \mathrm{~kg} \mathrm{~m}^{2}, \mathrm{~J}_{\mathrm{zz}}=0.0095 \mathrm{~kg} \mathrm{~m}^{2}$,

$>$ weight of water displaced at immersion $\mathrm{h}_{\mathrm{z}}=1.4 \mathrm{~m}, \mathrm{~m}_{\mathrm{z}}=13.539 \mathrm{~kg}$.

A diagram of the immersion and installation of a single buoyancy element is presented in Figure 9. Vertical line number 5 keeps the element in the vertical position. It was attached to the bottom of the basin at one end and to the lower end of the tube at the other. The horizontal lines numbers 1-4 prevented the buoyancy element from moving along the horizontal direction. At one end, they were attached to the simulated basin bottom, while at the other they were fastened to the tube at a distance of $0.25 \mathrm{~m}$ and $1 \mathrm{~m}$ measured from the lower end of the tube. The modelling procedure of the tube element required the division of a tube of length $\mathrm{L}=1.5 \mathrm{~m}$ into multiple smaller parts of $0.25 \mathrm{~m}$ each, which resulted in 6 equal tube segments. All the lines were made of artificial fibres with a carbon fibre core (sailboat line with a diameter of $0.008 \mathrm{~m}$ ). The tensile strength $\mathrm{E}_{\mathrm{A}}$ of the line (the product of Young's modulus and the line's cross-sectional area), determined experimentally in the material durability laboratory at the Maritime University in Szczecin, was $E_{A}=10^{5} \mathrm{~N}$. The calculated elastic constants $\mathrm{k}=\mathrm{E}_{\mathrm{A}} / \mathrm{L}$ for the respective lengths of line were equal to:

$>$ for a vertical line of length $\mathrm{L}_{5}=1.61 \mathrm{~m}, \mathrm{k}_{5}=10^{5} / 1.61=0.6210^{5} \mathrm{~N} / \mathrm{m}$,

$>$ for a horizontal lines of length $\mathrm{L}_{1}=1.0 \mathrm{~m}, \mathrm{k}_{1}=\mathrm{k}_{2}=\mathrm{k}_{3}=\mathrm{k}_{4}=10^{5} \mathrm{~N} / \mathrm{m}$.

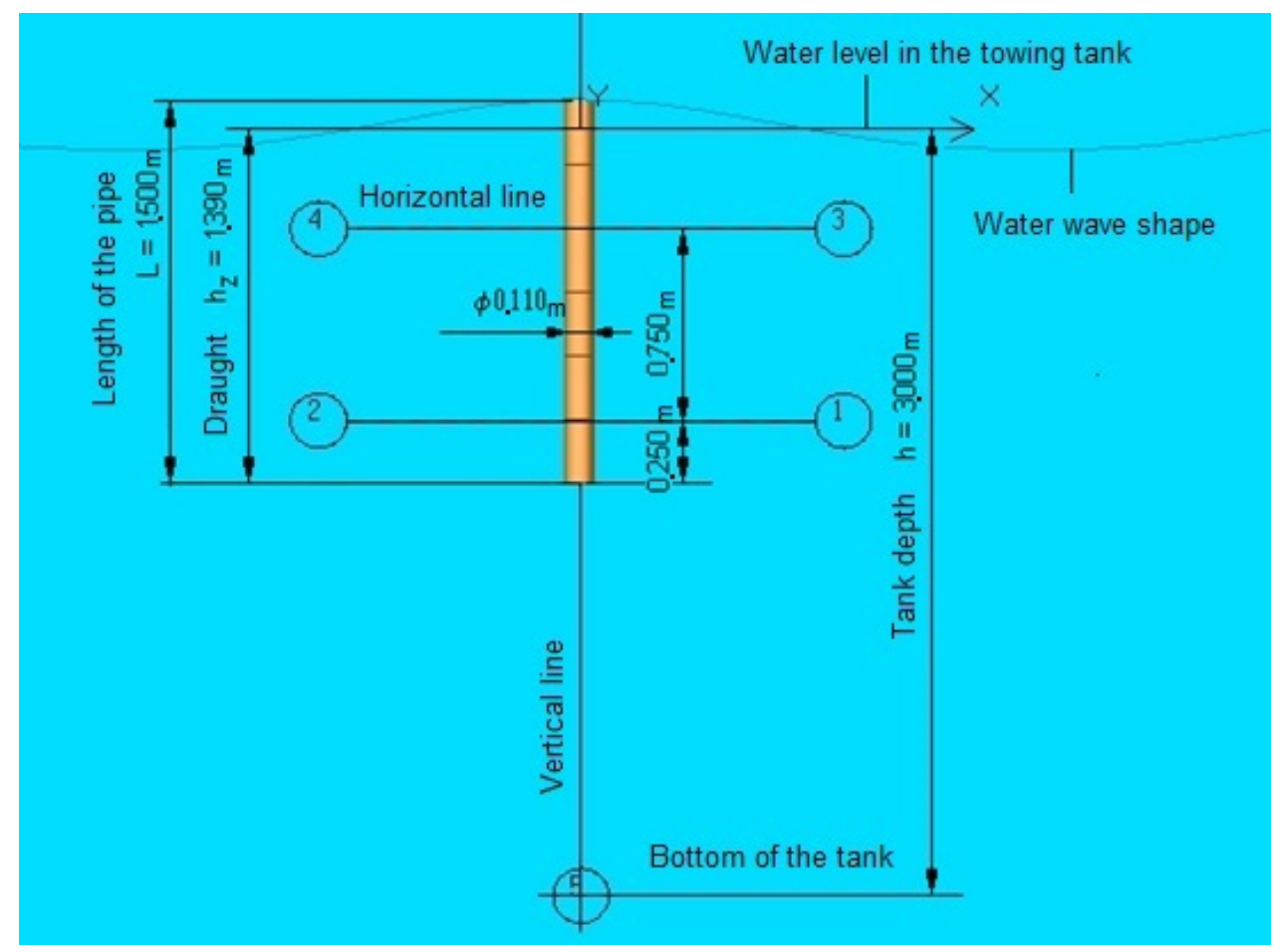

Figure 9. Diagram of the immersion of one buoyancy element in the basin. 
Computer calculations of the loads were performed using the ANSYS AQWA OFFSHORE v 12.1 software (ANSYS Inc., Canonsburg, PA, USA). A view of the element modelled has been shown in Figure 10.

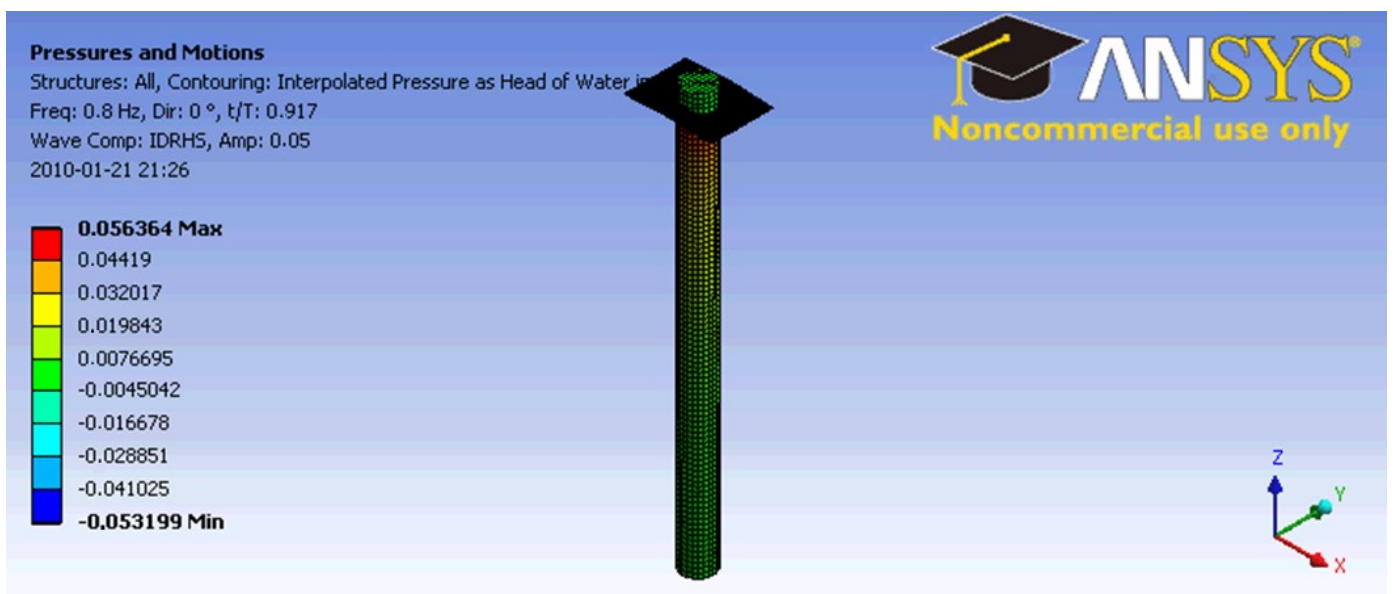

Figure 10. Example pressures and motion results for the buoyancy element modelled in ANSYS AQWA OFFSHORE.

The results of the calculations of the horizontal forces in horizontal lines 1-4 and the vertical forces in the vertical line 5 with wave amplitude of $0.05 \mathrm{~m}$ are shown in Figure 11. Fluctuations of the vertical force of line 5 were within the range of 94.1-95.4 N. The average value of the signal was equal to $94.75 \mathrm{~N}$, and the amplitude was $0.65 \mathrm{~N}$. There was, therefore, almost a constant line tension caused by the buoyancy force of a single tube. Water rippling had a minimal effect on the vertical forces. The forces in the horizontal line range around the average value were equal to zero, and the amplitude of these oscillations in the lower lines was approximately $2 \mathrm{~N}$, while in the upper lines it was approximately $9 \mathrm{~N}$.

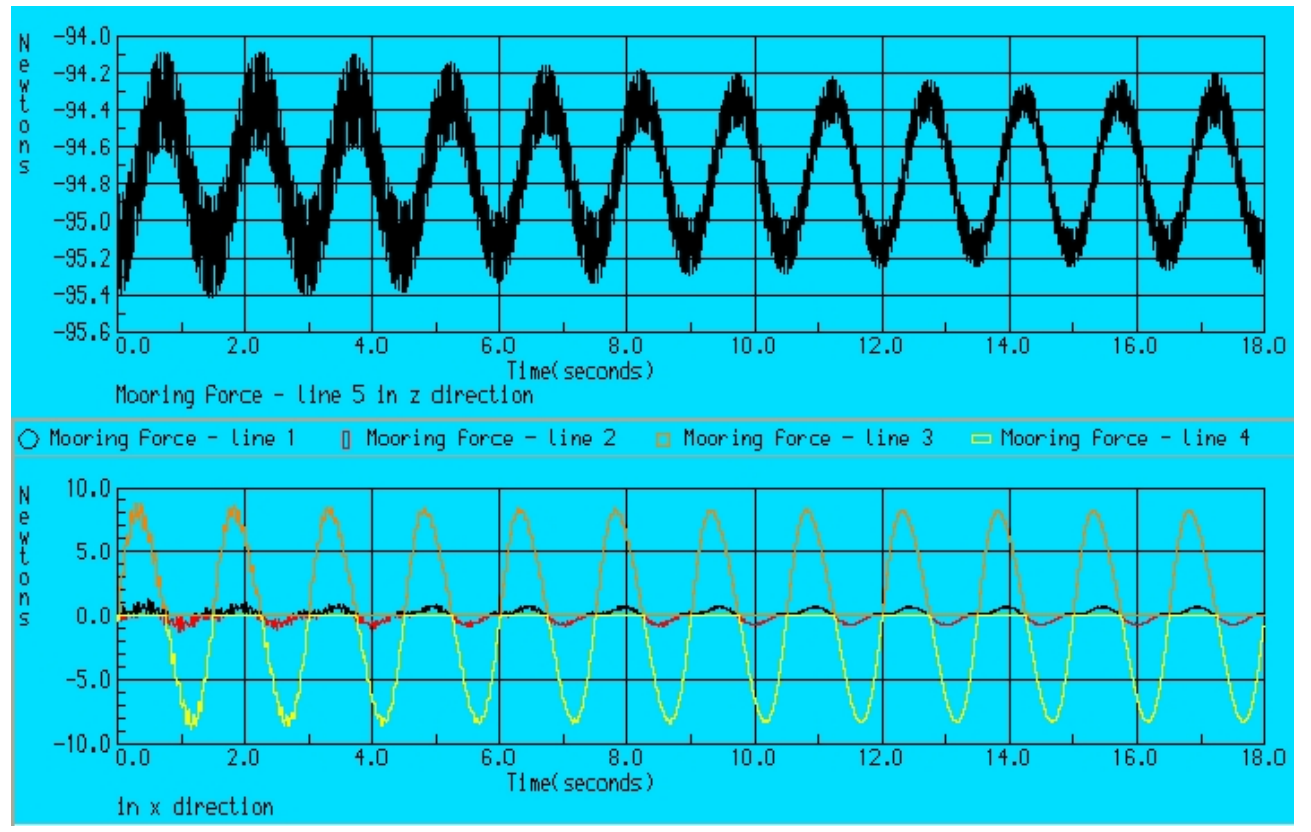

Figure 11. The results of the computer calculations of the forces in the lines with wave amplitude of $0.05 \mathrm{~m}$ (vertical line: number 5, horizontal lines: numbers 1-4). 
Figure 12 presents the same processes, but was obtained with an amplitude twice as large $(0.1 \mathrm{~m})$. The range of fluctuations of the vertical force in line 5 was increased and was in the range from 85 to $105 \mathrm{~N}$. The average value of this signal remained at $94.75 \mathrm{~N}$, and the maximum amplitude increased to $10 \mathrm{~N}$. The amplitude of the signals of the horizontal forces in the lower lines (numbers 1 and 2) was approximately $5 \mathrm{~N}$, and in the top lines (numbers 4 and 5 ) it approximately equalled $25 \mathrm{~N}$. It can be clearly seen that the signals of the lower and upper horizontal forces were in opposite phases.

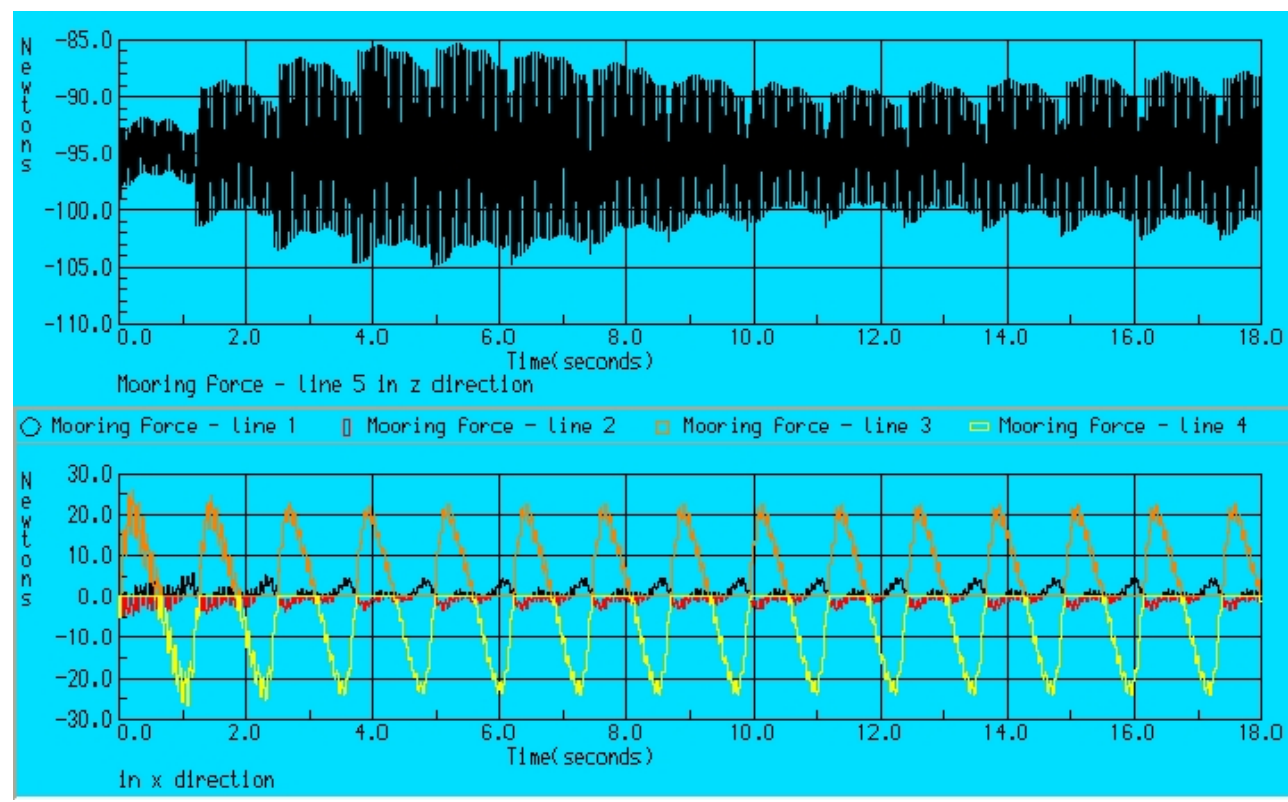

Figure 12. Results of the computer calculations of the forces in the lines with wave amplitude of $0.1 \mathrm{~m}$ (vertical line number 5, horizontal lines numbers 1-4) [1].

Figure 13 shows an overview of the signals of the horizontal forces as determined from second 11 to 17 of the simulation. The opposite phases of the signals of the forces in the upper lines (numbers 3-4) compared to forces in the lower lines (numbers 1-2) were clearly seen.

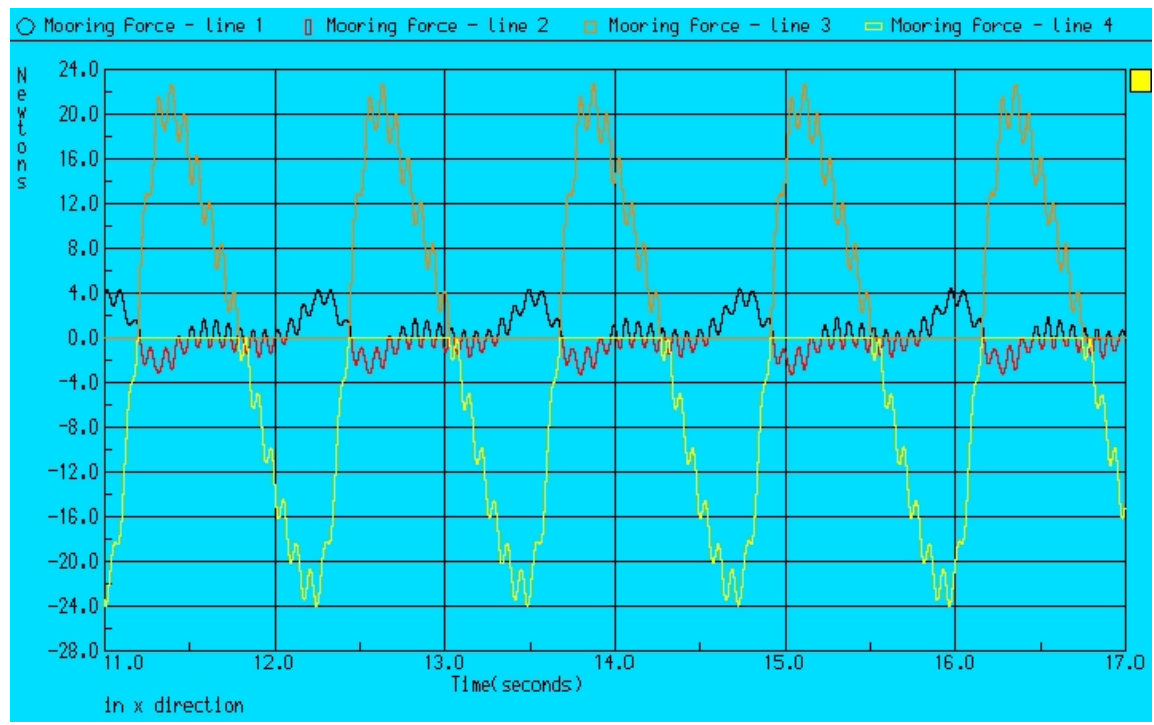

Figure 13. Determined signals of the horizontal forces [1]. 
Both wave amplitudes of $0.05 \mathrm{~m}$ and $0.10 \mathrm{~m}$ confirmed the fact that the wave amplitude decreased exponentially along with the depth. At the depth equal to half the wave length, the wave motion was damped by as much as 23 times [15].

\subsubsection{Load Modelling of Two Elements}

The diagram in Figure 14 shows the distribution of two buoyancy elements attached using vertical lines to the basin bottom and connected to each other at a distance equal to half the length of the wave. A view of the modelled elements is shown in Figure 15.

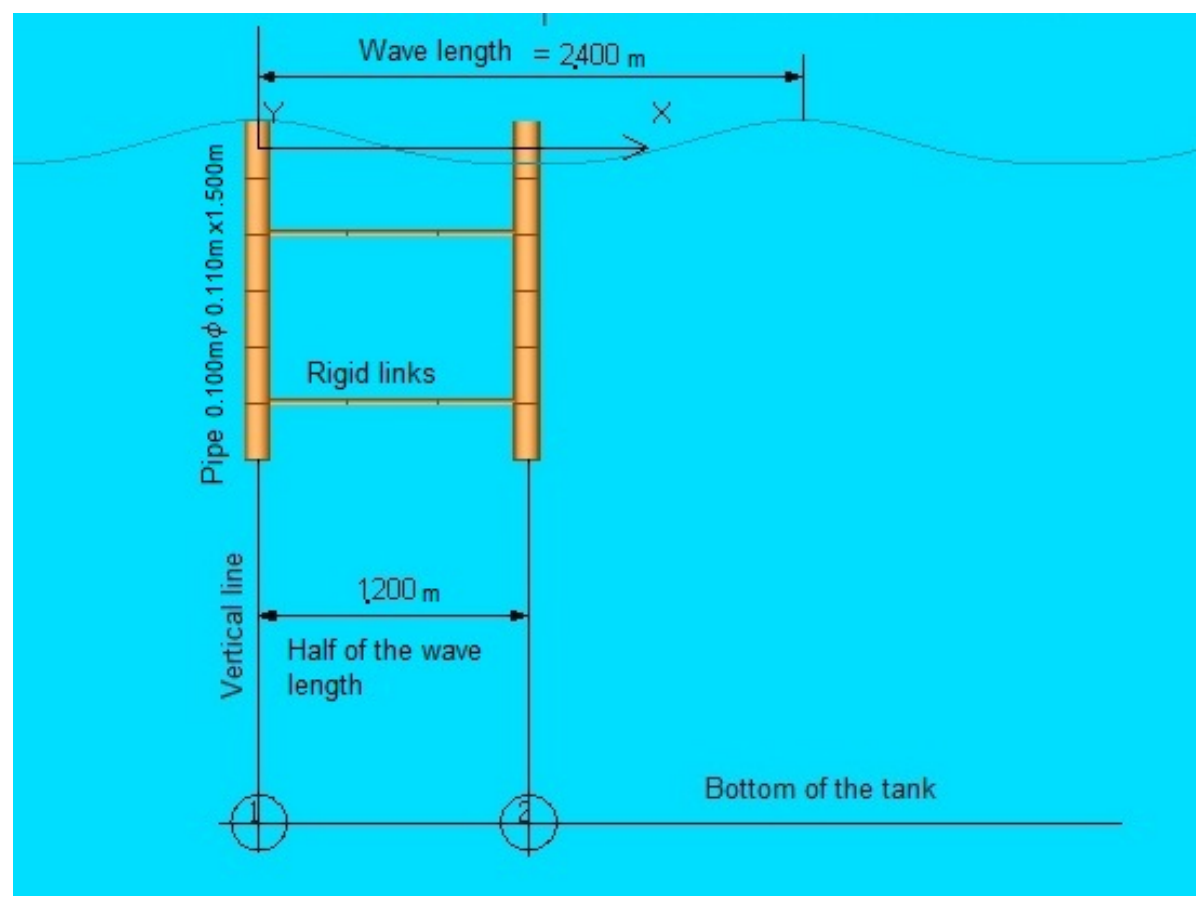

Figure 14. A diagram of the distribution of two buoyancy elements spaced at a distance equal to half the wave length.

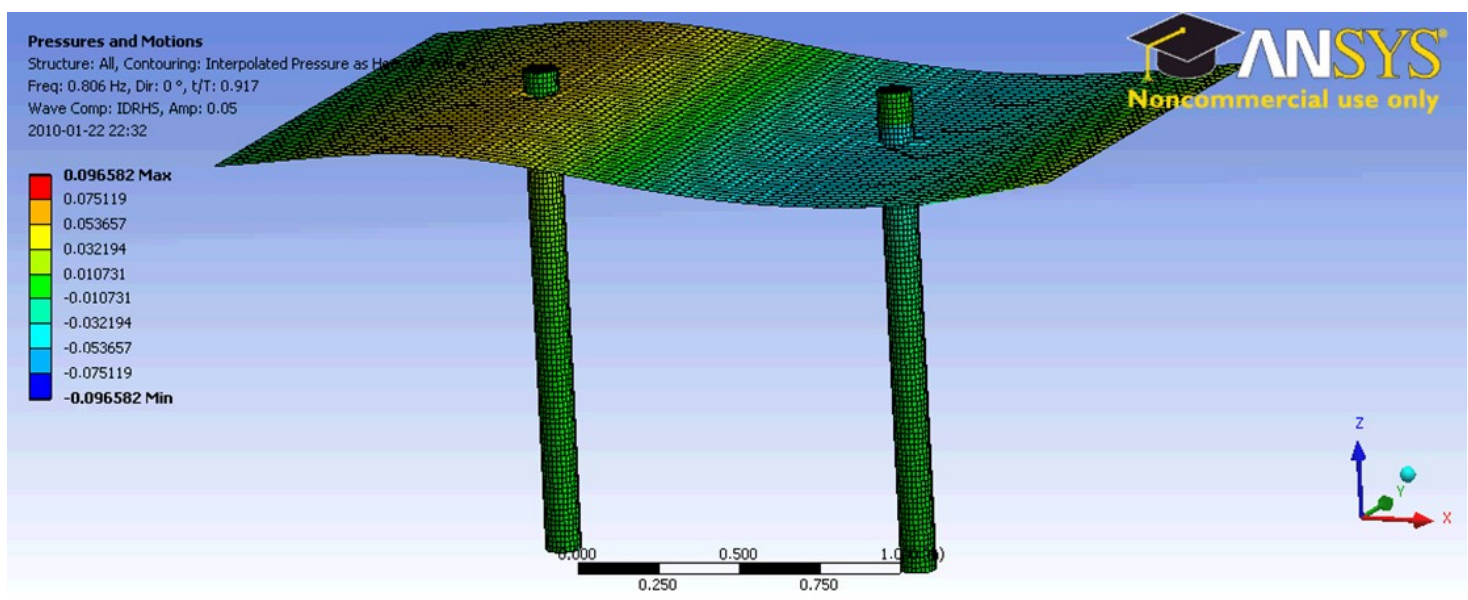

Figure 15. Example pressures and motion results for the pair of buoyancy elements modelled using ANSYS AQWA OFFSHORE. 
These are two identical elements as shown in Figure 9, attached to the bottom of the basin with identical lines and at the same depth. The fundamental difference here lay in the use of rigid connectors between the two tubes instead of horizontal lines. The connectors are at a depth equal to the depth of the horizontal lines in Figure 9. Figures 16 and 17 present the results of the computer simulation of the values of the forces in the vertical line and rigid connectors respectively, at wave amplitudes equal to $0.05 \mathrm{~m}$ and $0.10 \mathrm{~m}$.

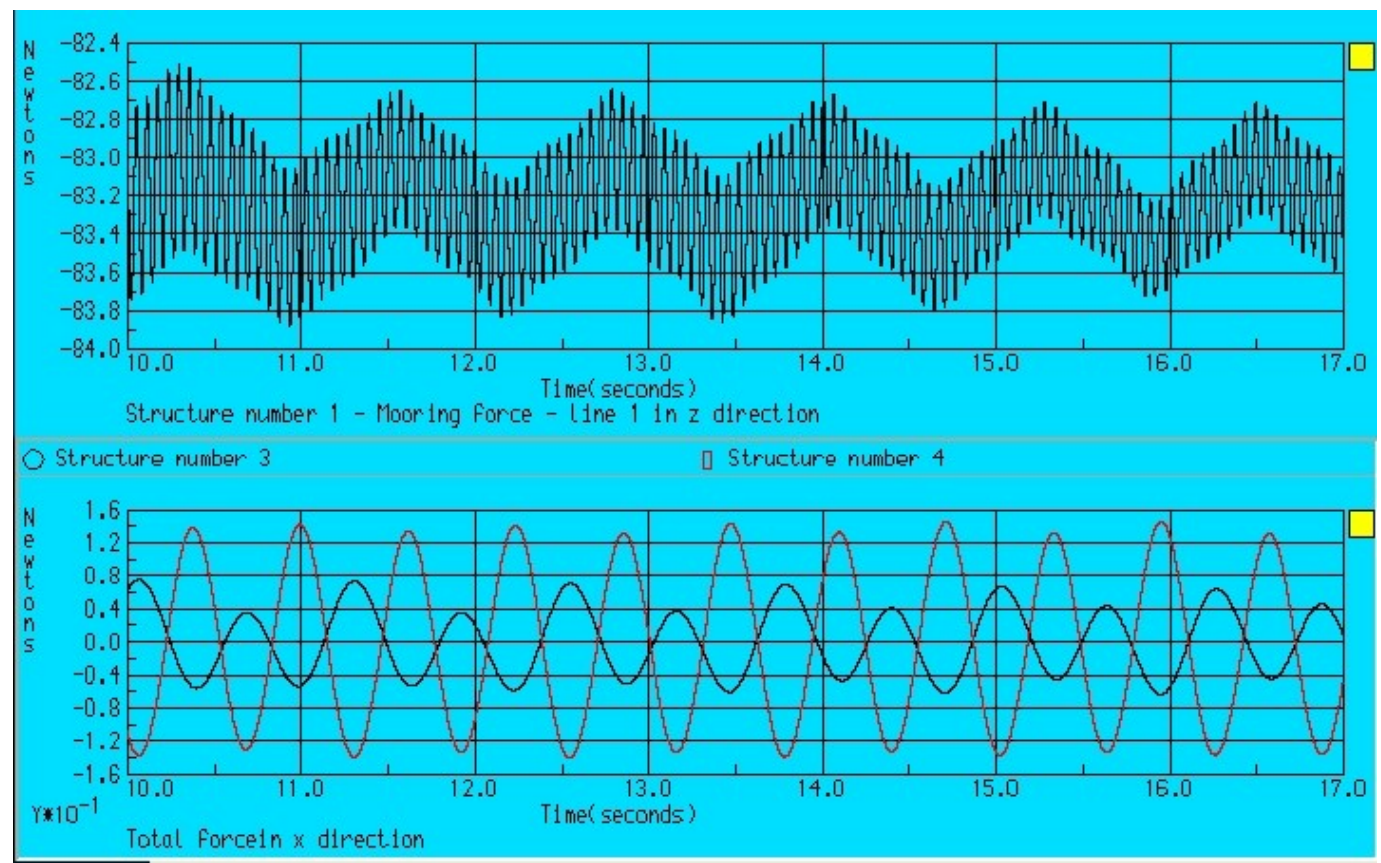

Figure 16. The results of the computer calculations of the forces in the vertical lines and rigid connectors at the amplitude of the wave equal to $0.05 \mathrm{~m} \mathrm{[1].}$

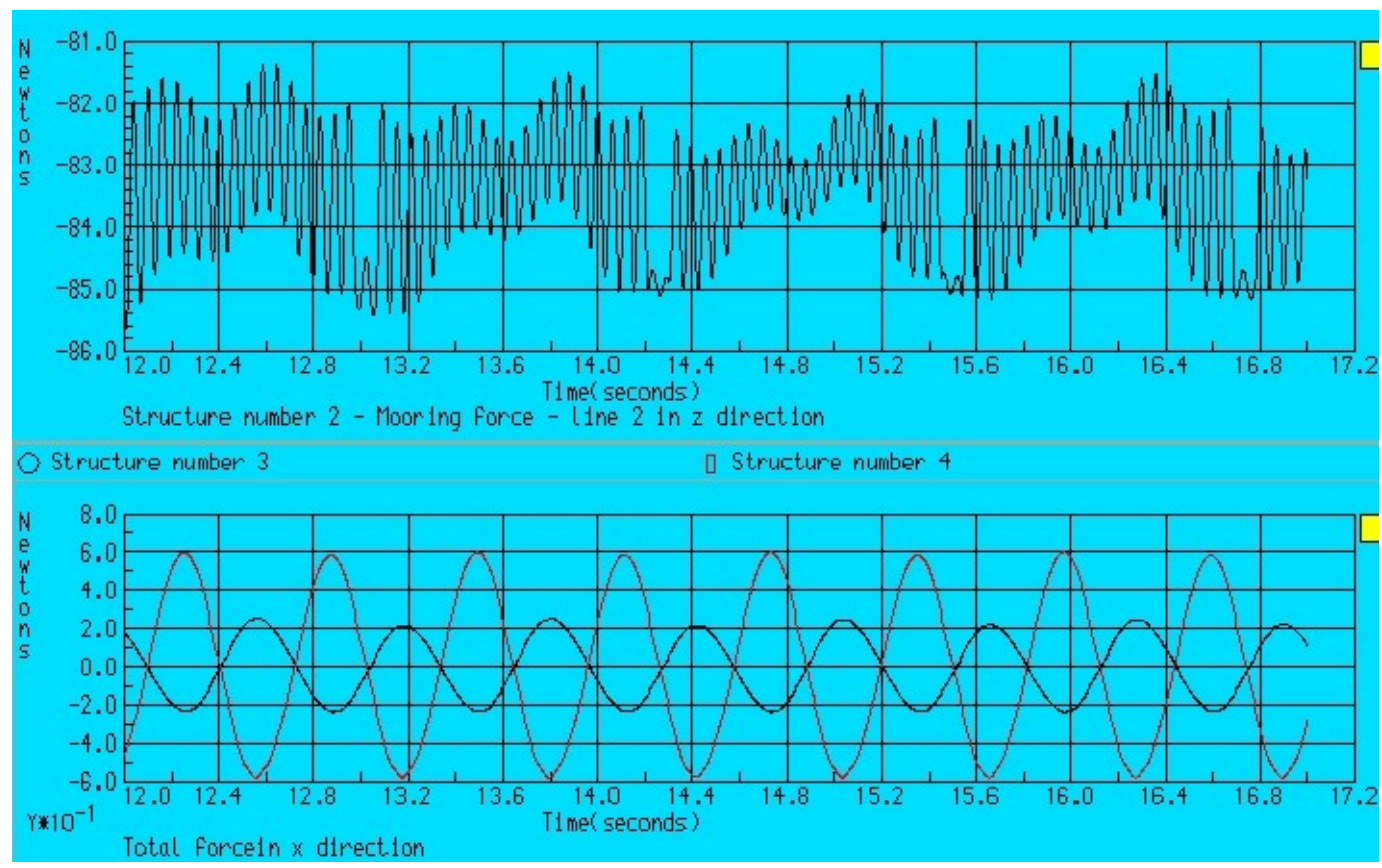

Figure 17. The results of the computer calculations of the forces in the vertical lines and rigid connectors at the amplitude of the wave equal to $0.10 \mathrm{~m}[1]$. 
The joints between the connectors and the tubes are articulated. The advantage of rigid connectors is that they can transfer the compression and extension forces.

\subsection{Experimental Studies}

The test site is presented in Figure 18. The first prototypes of the damping device were constructed from polyethylene tubes with a diameter of $0.11 \mathrm{~m}$ and length of $1.5 \mathrm{~m}$ installed vertically at the vertices of equilateral triangles with sides equal to $0.505 \mathrm{~m}$. The studies undertaken have demonstrated the correct functioning of the first prototype of the damping device, but the results of the damping were considered to be insufficient. The results obtained clearly indicated that the main issue standing in the way of creating the second prototype was an increase in the damping force of the first prototype. To improve the damping properties of the device, a single row of rigid elements was attached vertically to each of the unit's trusses that were made of water-resistant plywood with a thickness of $0.02 \mathrm{~m}$, a width of $0.1 \mathrm{~m}$ and a length of $1.5 \mathrm{~m}$. Twelve additional elements were added to the first damping unit from the side of the wave direction, while the second unit which affects the already partially damped waves was reinforced with eighteen additional items.

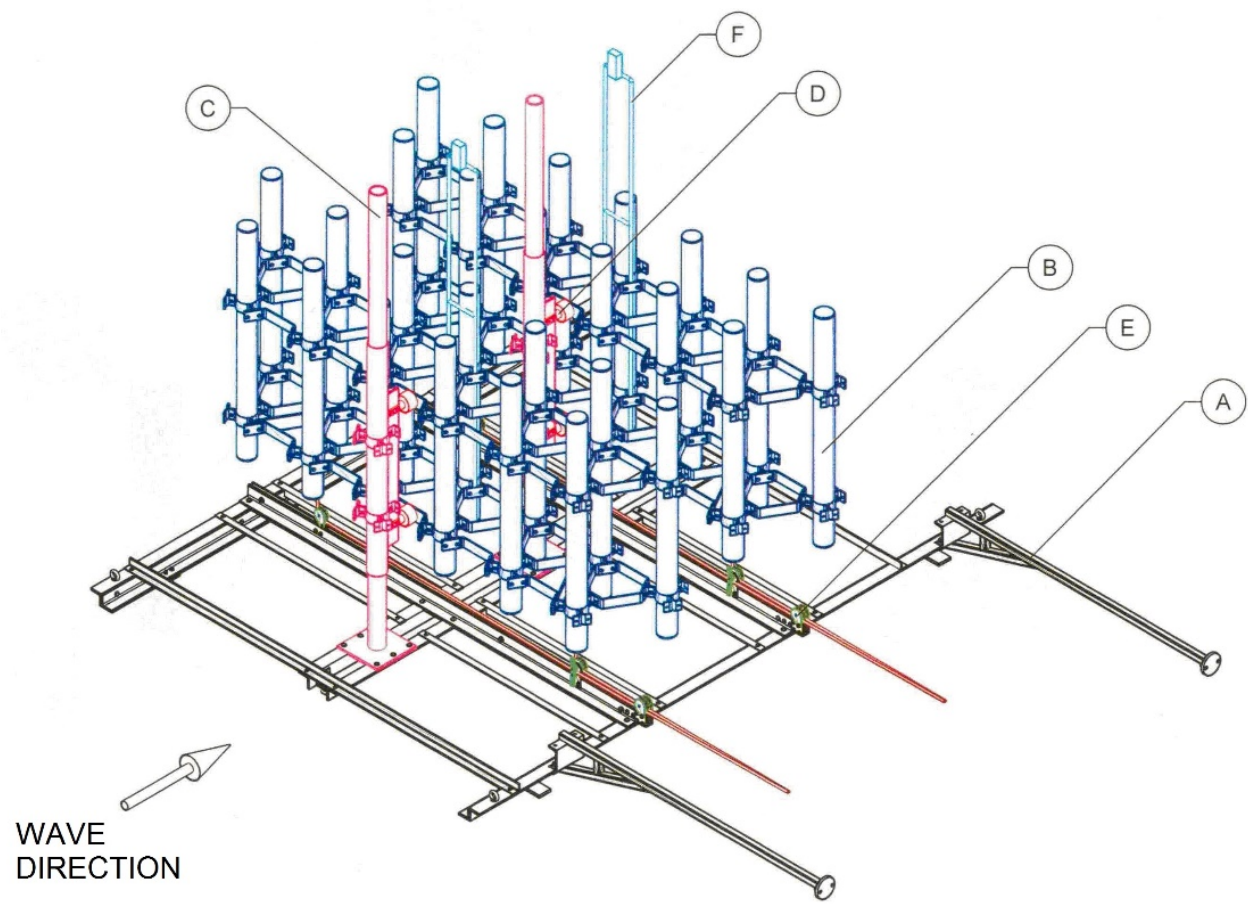

Figure 18. Diagram of the testing stand for damping device prototypes: (A) frame unit; (B) damping units; (C) rail system; (D) force measurement system; (E) immersion adjustment system; (F) immersion measurement system [25].

The metrological parameters of the generator allowed the production of a wave with the assumed length of $2.4 \mathrm{~m}$ with an accuracy of $0.005 \mathrm{~m}$. To measure the profile of the wave, resistance probes were used with an uncertainty range of less than $0.0015 \mathrm{~m}$ at a $95 \%$ confidence level. Since the sinusoidal wave generated can be seen as an ergodic phenomenon, the Tps2* section for the probe S2 can be used for the analysis and development of the measurement data which was recognized to be undistorted. While in the case of the probe S1, a section was used that was equal to the first one in terms of parameter values, but shifted back in time by $22 \mathrm{~s}$. This is shown schematically in Figure 19. 


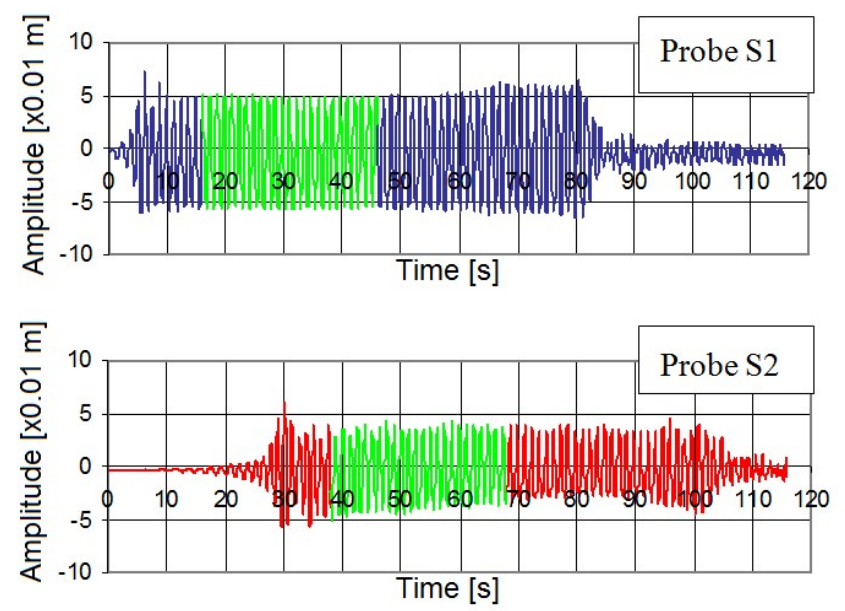

Figure 19. The pattern for the selection of data for the determination of average amplitudes (with measurement number 24 as an example). The light green colour indicates the selected time sections for the analysis.

Figure 20 presents the measurement results of the wave height, H1, in front of the device and $\mathrm{H} 2$ behind the damping device. Figure 21 shows the measurement results of the horizontal force sensors for the same sample: $1.1 ; 2.1$; this sample was tagged as pom36 in the Maritime University report.

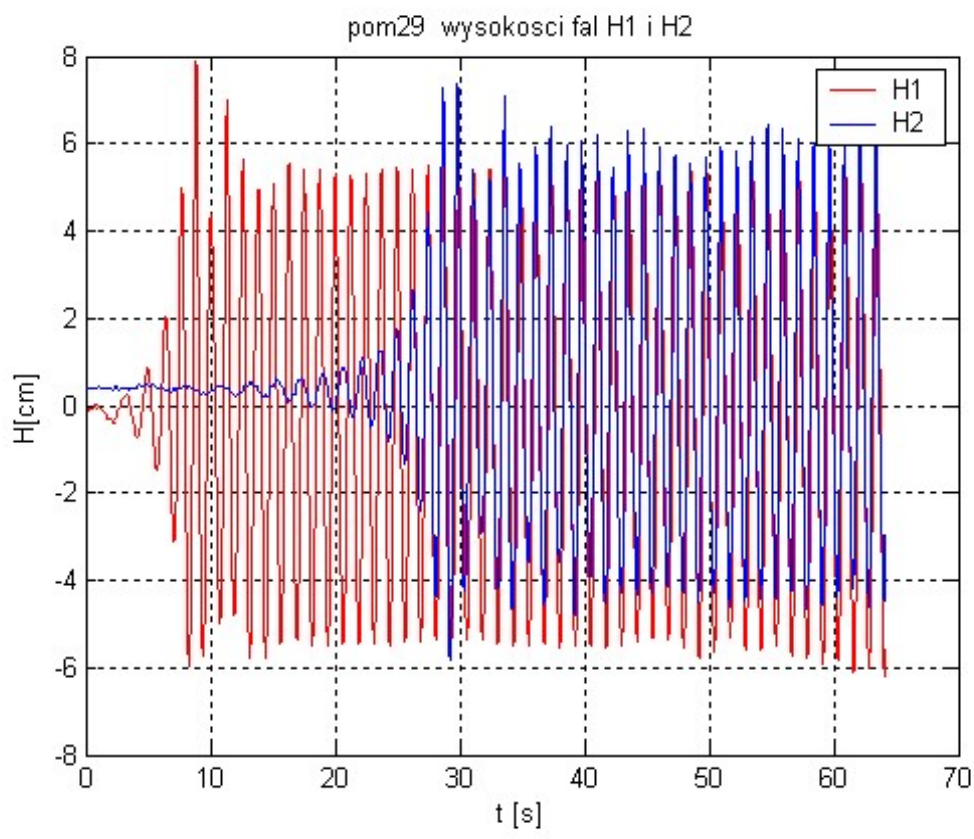

Figure 20. Results of the wave height measurement.

The prototype functioned properly and in accordance with the project thesis, and demonstrated damping properties in accordance with the report of the Ship Hydromechanics Division, Ship Design and Research Centre (CTO S. A.) of approximately 30\%, as shown in Figure 22. However, these damping values were considered unsatisfactory. The conclusions from this series of tests was that further investigation was needed in order to create another prototype with much better damping characteristics through the application of additional dissipative elements that would also limit the circular motion of the rippling water molecules in the vertical direction. It was assumed that this was to be achieved with a limited number of elements that would not violate the above condition of stability. This device structure 
was positively experimentally tested. The additional dissipative elements were cords made of round plastic (polyethylene, PE) elements that are used in swimming pools to distinguish swimming lanes.

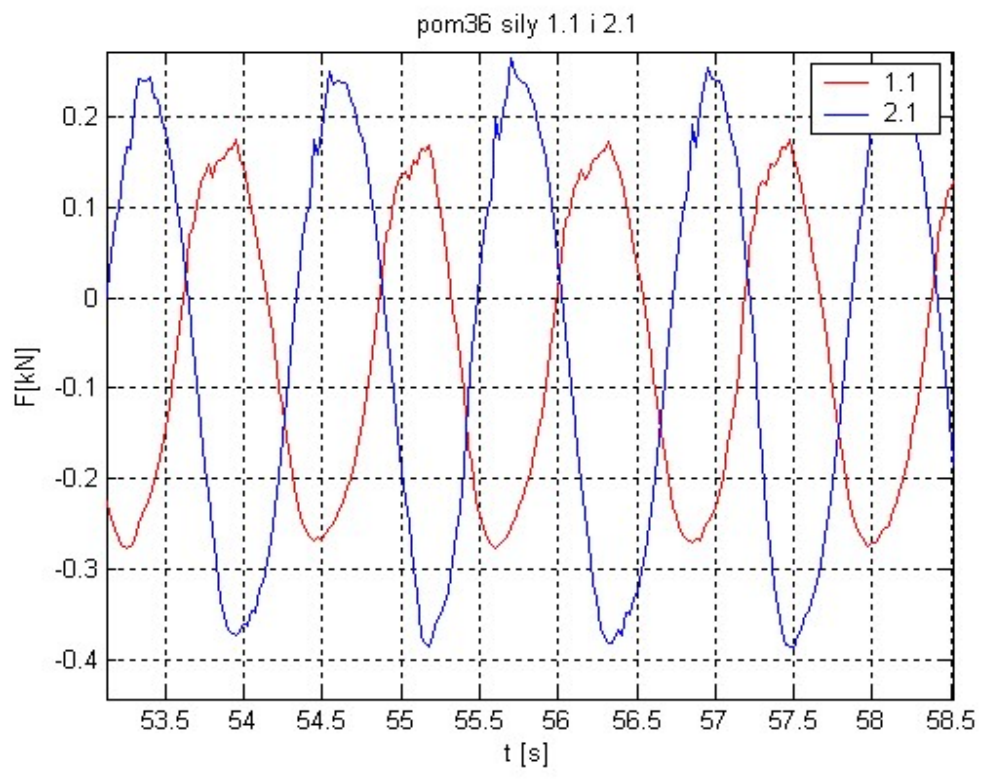

Figure 21. Results of horizontal force measurement.

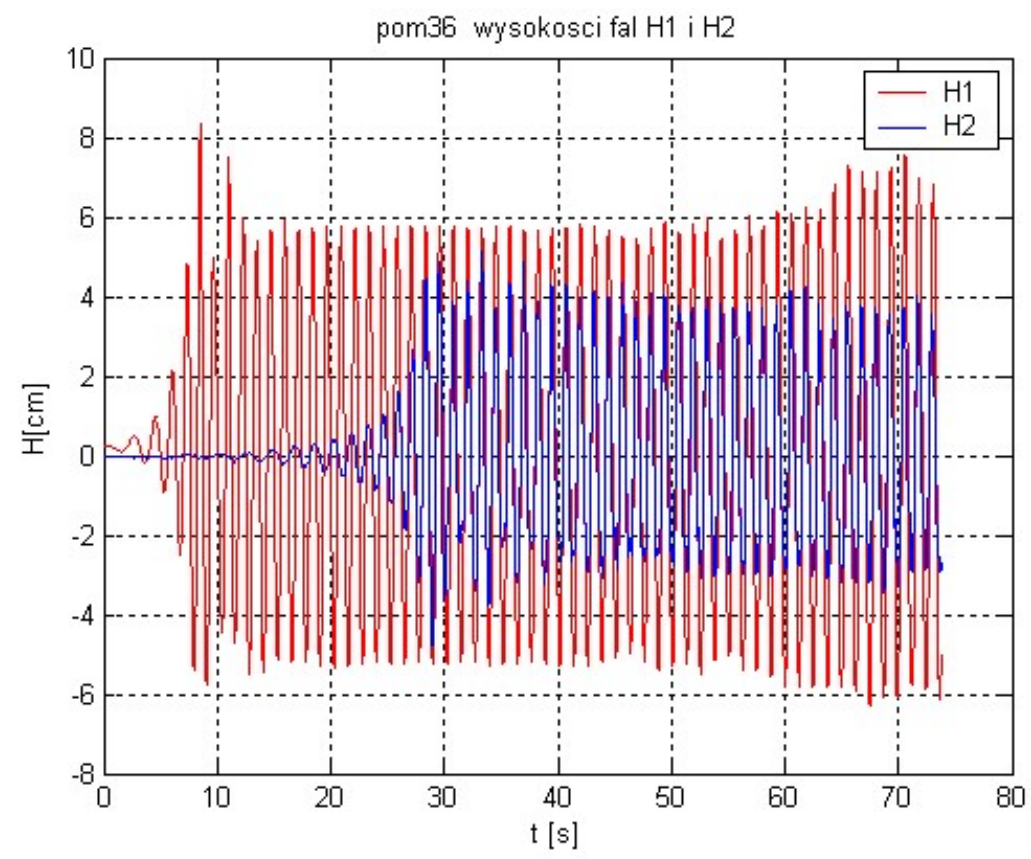

Figure 22. Graphs displaying the wave height in front of and behind the damping device with no additional dissipative elements.

Table 2 provides an overview of the results of the experimental study of wave damping. Measurements marked with an asterisk $\left({ }^{*}\right)$ are for devices with additional dissipative elements, negative draught means surfacing, and Hs1 and Hs2 mark the wave height in front and behind the damping device respectively. 
Table 2. The test results of the damping device, with the same value of draught for both units (attempt 15,377 and 15,378) developed by the Ship Design and Research Centre.

\begin{tabular}{cccccc}
\hline Measurement Number & Draught & Hs1 & Hs2 & Damping & Error \\
\hline & {$[\mathrm{m}]$} & {$[\mathrm{m}]$} & {$[\mathrm{m}]$} & {$[\%]$} & {$[\%]$} \\
\hline 36 & -0.0500 & 0.1101 & 0.0712 & 35.5 & 1.4 \\
26 & -0.0500 & 0.1068 & 0.0798 & 25.3 & 1.4 \\
$37^{*}$ & 0.2000 & 0.1109 & 0.0920 & 17.0 & 1.4 \\
$38^{*}$ & 0.1500 & 0.1086 & 0.0865 & 20.3 & 1.4 \\
$39 *$ & 0.1000 & 0.1091 & 0.0785 & 28.0 & 1.4 \\
$40^{*}$ & 0.0500 & 0.1094 & 0.0631 & 42.3 & 1.4 \\
$41^{*}$ & 0.0000 & 0.1086 & 0.0486 & 55.3 & 1.4 \\
$42^{*}$ & -0.0500 & 0.1097 & 0.0371 & 66.2 & 1.4 \\
$43^{*}$ & -0.1000 & 0.1096 & 0.0375 & 65.8 & 1.4 \\
$44^{*}$ & -0.1000 & 0.1443 & 0.0394 & 72.7 & 1.0 \\
$45^{*}$ & 0.0000 & 0.1406 & 0.0511 & 63.7 & 1.1 \\
$46^{*}$ & 0.0000 & 0.1565 & 0.0540 & 65.5 & 1.0 \\
\hline
\end{tabular}

$\left(^{*}\right)$ devices with additional dissipative elements.

The highest damping efficiency was obtained for measurement number 44 , which exceeded $70 \%$. Figures 23-25 present the course of the vertical and horizontal forces in the device and the value of compensation of the horizontal forces for the device equipped with additional dissipative elements.

The results presented show that the application of Kuźniewski's damper can attenuate waves in a wide range of values-by tens of percent up to values greater than $70 \%$. They also demonstrated the high level of possible compensation of the horizontal forces with small amplitudes of vertical forces. These results have proven the validity of the assumptions for the tested device.

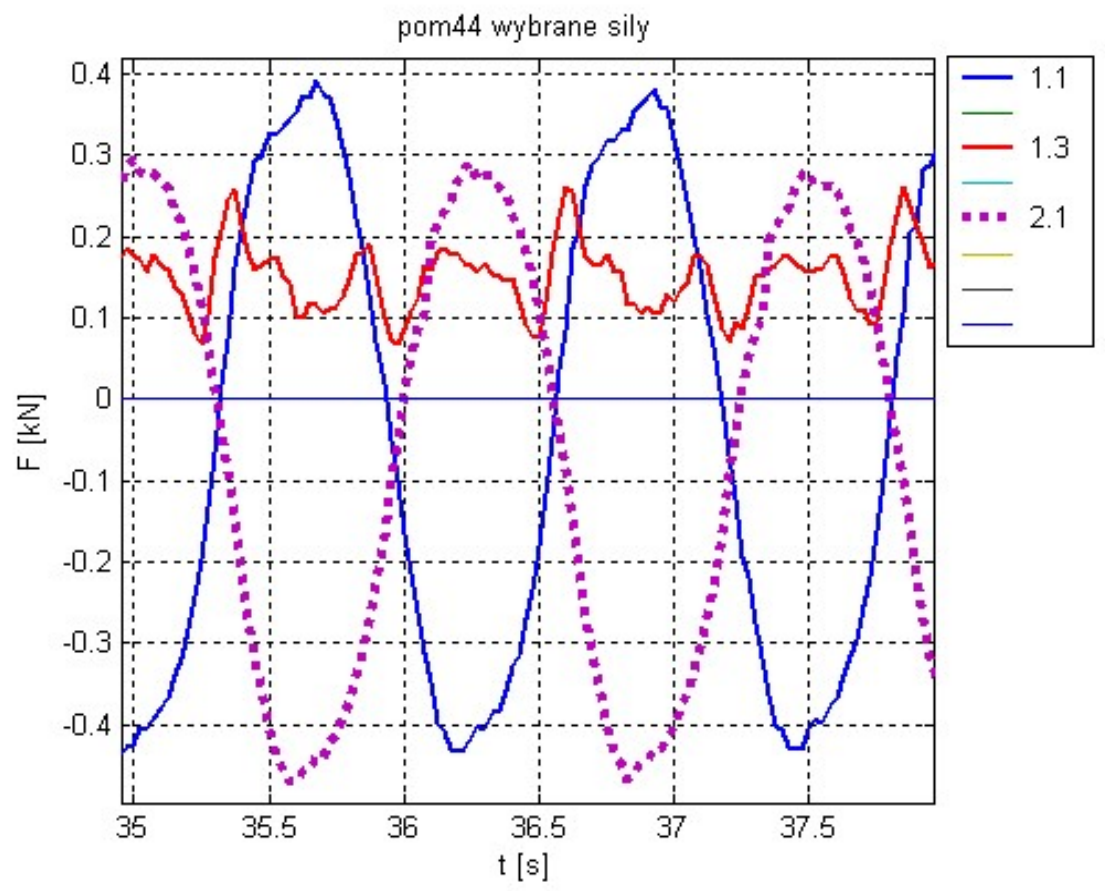

Figure 23. Distribution of horizontal forces 1.1 and 2.1 and the course of the vertical force 1.3 with a significantly smaller amplitude. 


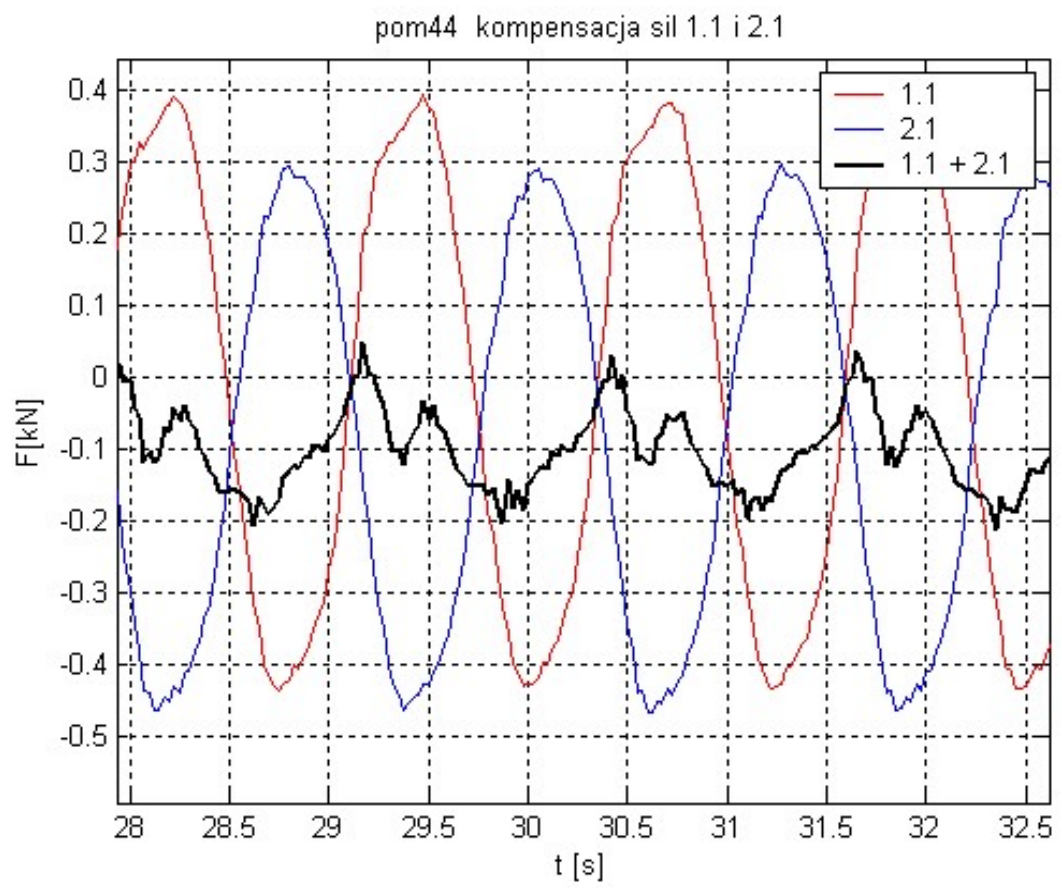

Figure 24. Compensation of the horizontal forces 1.1 and 2.1.

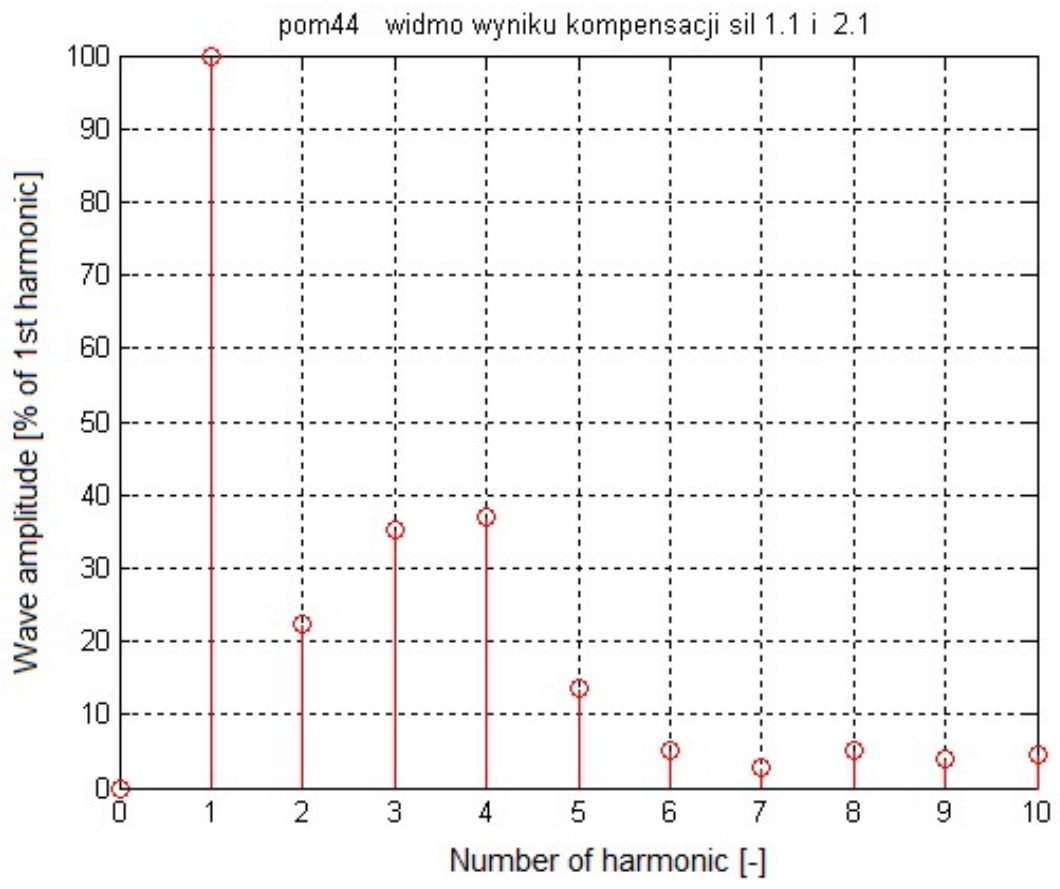

Figure 25. Amplitude spectrum of the compensation value of the horizontal forces 1.1 and 2.1.

\section{Conclusions}

The experimental tests, performed at the model basin of the Ship Hydromechanics Division, Ship Design and Research Centre (CTO S. A.) in Gdańsk (Poland), have confirmed that the damping device functioned in accordance with the design assumptions. The results demonstrated damping of waves by more than $70 \%$ and a high level of compensation of horizontal forces. The results of the experimental studies were consistent with those obtained by means of computer simulations. 
The physical basis for the presented device concept is a representation of the assumption described in the scientific literature that the motion of molecules of rippling water occurs in the layer of thickness that is near half of the wave length and occurs in vertical planes along the lines of partly closed circles.

The simulation calculations showed that the horizontal forces acting on a single tube immersed vertically in rippling water occurring by the upper end of the tube were much stronger than the horizontal forces appearing at the bottom end of the tube. In addition, the simulation calculations for two tubes immersed in rippling water placed at a distance equal to half the wave length and tied to each other with a rigid connector demonstrated the maintenance of a stable position which implies a compensation for the horizontal forces.

The modular design of the damping device allows for any configuration and size of the structure. The design work was supported by cutting-edge computer modelling software. The design features of the device ensure its durability, stability in rippling water and the possibility to adjust the damping force by attaching the required number of highly dissipative elements to both units.

The experimental research undertaken provides confirmation of the two hypotheses: "the largest damping force should occur when the damping units are placed at an optimal distance equal to half the length of the wave to be damped" and "a compensation of the horizontal forces caused by the rippling of water should occur in the damping device".

The positive results of the experimental studies, after their verification and further development in more complex sea conditions, including those associated with the use of new structural materials $[26,27]$, create the possibility for practical application of the new method of coastal protection against storm waves.

\section{Patents}

Kuźniewski B., Sposób ochrony brzegu przed falami morskimi i zespół tłumiący energię fal morskich [The manner of embankment protection against sea waves and unit dampening energy of sea waves]. Patent PL 210447, Polish Patent Office, 23.03.2007.

Acknowledgments: The article is a tribute to the scientific oeuvre of Professor Bolesław Kuźniewski (22 June 1935-20 August 2017), inventor and innovator, outstanding specialist in the field of applied fluid mechanics and the creator of the solution presented in this article. The article has presented the results of studies that are part of the research project N R03 002804 funded by the National Centre for Research and Development (Poland) titled 'Nowy sposób ochrony brzegów przed falami morskimi' (A new method for coastal protection against sea waves) under the leadership of Zenon Grzadziel. The publication costs was covered from the grant of the Ministry of Science and Higher Education of Poland No. 1/S/IESO/17 titled 'Increasing operational effectiveness of complex technical systems by systematic development and implementation of innovations using novel materials and modifying the object's structure' performed at the Institute of Marine Propulsion Plants Operation, Faculty of Marine Engineering, Maritime University of Szczecin.

Author Contributions: Leszek Chybowski wrote the paper, performed the analysis of the state-of-the-art, consolidated the data, recalculated the data in the tables, and built the conclusions. Zenon Grzadziel built mathematical models and performed simulations. Katarzyna Gawdzińska participated in the analysis of the state-of-the-art as well as in building conclusions.

Conflicts of Interest: The authors declare no conflict of interest.

\section{References}

1. Kuźniewski, B.; Grządziel, Z. Symulacja komputerowa i doświadczalna weryfikacja obciążeń działających na elementy urządzenia tłumiącego falowanie wody. Mechanik 2010, 83, 424. (In Polish)

2. Chybowski, L.; Kuźniewski, B. Zespół Maszynowy Napędzany Przepływem Płynu oraz Sposób jego Mocowania [Liquid Flow Based Operation-type Machine Assembly]. Patent PL 227343, 21 August 2015.

3. Falcao, V. First-generation wave power plants: Current status and R and D requirements. J. Offshore Mech. Arctic Eng. 2004, 126, 384-388. [CrossRef]

4. Falcao, V. Wave energy utilization: A review of the technologies. Renew. Sustain. Energy Rev. 2010, 14, 899-918. [CrossRef] 
5. Kuźniewski, B. Podwodny Zespół Prądotwórczy [Underwater Generator Set]. Patent PL 223873, 23 December 2013.

6. Ning, D.Z.; Zhao, X.L.; Chen, L.F.; Zhao, M. Hydrodynamic Performance of an Array of Wave Energy Converters Integrated with a Pontoon-Type Breakwater. Energies 2018, 11, 685. [CrossRef]

7. Zhong, H.-F.; Sun, Y.-H.; Han, S.-Y.; Zhou, J.; Wang, D. Digital-Control-Based Approximation of Optimal Wave Disturbances Attenuation for Nonlinear Offshore Platforms. Energies 2017, 10, 1997. [CrossRef]

8. Zółkiewski, S. Attenuation-frequency characteristics of beam systems in spatial motion. Solid State Phenom. 2010, 164, 349-354. [CrossRef]

9. Chybowski, L.; Kuźniewski, B. An overwiew of methods for wave energy conversion. Sci. J. Marit. Univ. Szczec. Zesz. Nauk. Akad. Morskiej Szcz. 2015, 41, 17-23. [CrossRef]

10. Javanmardi, M.; Binns, J.; Izham, M.I.C.; Rafieshahraki, J. The effect of angle of attack on the generated wave propagation. Sci. J. Marit. Univ. Szczec. Zesz. Nauk. Akad. Morskiej Szcz. 2017, 50, 36-41. [CrossRef]

11. Franzitta, V.; Curto, D. Sustainability of the renewable energy extraction close to the Mediterranean islands. Energies 2017, 10, 283. [CrossRef]

12. Franzitta, V.; Catrini, P.; Curto, D. Wave energy assessment along Sicilian coastline, based on DEIM point absorber. Energies 2017, 10, 376. [CrossRef]

13. Chybicki, W. Teoria fal Powierzchniowych w Strefie Zmiennej Głębokości Wody; Wydawnictwo Instytutu Budownictwa Wodnego PAN Gdańsk: Gdańsk, Poland, 2006; ISBN 83-85708-71-5. (In Polish)

14. Bernhoff, H.; Sjöstedt, E.; Leijon, M. Wave energy resources in sheltered sea areas: A case study of the Baltic Sea. Renew. Energy 2006, 31, 2164-2170. [CrossRef]

15. Gurgul, H. Hydrodynamika Morza; Wydawnictwo Naukowe Uniwersytetu Szczecińskiego Szczecin: Szczecin, Poland, 2001; ISBN 83-7241-147-6. (In Polish)

16. Franzitta, V.; Curto, D.; Milone, D.; Rao, D. Assessment of renewable sources for the energy consumption in Malta in the Mediterranean Sea. Energies 2016, 9, 1034. [CrossRef]

17. Living with Coastal Erosion in Europe: Sediment and Space for Sustainability PART II-Maps and Statistics. Directorate General Environment European Commission. Service Contract B4-3301/2001/329175/MAR/B3 "Coastal erosion-Evaluation of the Need for Action". 29 May 2004. Available online: http:/ / www.eurosion. org/reports-online/part2.pdf (accessed on 18 March 2018).

18. Green Paper. Towards a Future Maritime Policy for the Union: A European Vision for the Oceans and Seas. Commision of the European Communities, COM(2006) 275 Final, Brussels, 7 June 2006. Available online: http: / / eur-lex.europa.eu/legal-content/EN/TXT/PDF/?uri=CELEX:52006DC0275(02)\&from=PL (accessed on 18 March 2018).

19. Breakwater (Structure). Available online: https:/ / en.wikipedia.org/wiki/Breakwater(structure) (accessed on 18 March 2018).

20. Sharifahmadian, A. Numerical Models for Submerged Breakwaters. In Coastal Hydrodynamics and Morphodynamics; Butterworth-Heinemann Oxford: Oxford, UK, 2016; ISBN 978-0-12-802413-3.

21. Stratigaki, V.; Troch, P.; Margheritini, L.; Kofoed, J.P. Estimation of wave conditions along a new breakwater for the Hanstholm harbour using the numerical model mildwave. In Proceedings of the International Offshore and Polar Engineering Conference, Rhodes, Greece, 17-22 June 2012; pp. 517-524.

22. Szmytkiewicz, M. Stosowane Metody Stabilizacji Brzegu Morskiego w Aspekcie zachowania i Odtwarzania plaż oraz Trwałość Stosowanych Rozwiązań. Jastarnia, 28 June 2010. Available online: http:/ / docplayer.pl/ 6170748-Stosowane-metody-stabilizacji-brzegu-morskiego-w-aspekcie-zachowaniai-odtwarzania-plaz-oraz-trwalosc-stosowanych-rozwiazan.html (accessed on 18 March 2018). (In Polish)

23. National Centre for Research and Development. Kreatorzy Innowacji. 2013. Available online: http:// www.ncbr.gov.pl/gfx/ncbir/userfiles/_public/monitoring/publikacje/innowacyjni_pol.pdf (accessed on 18 March 2018). (In Polish)

24. Kuźniewski, B. Sposób Ochrony Brzegu przed Falami Morskimi i zespół Tłumiący Energię fal Morskich [The Manner of Embankment Protection against Sea Waves and Unit Dampening Energy of Sea Waves]. Patent PL 210447, 23 March 2007.

25. Chybowski, L.; Kuźniewski, B. Utilising water wave energy-Technology profile. Sci. J. Marit. Univ. Szczec. Zesz. Nauk. Akad. Morskiej Szcz. 2016, 47, 183-186. [CrossRef] 
26. Gawdzińska, K.; Chybowski, L.; Przetakiewicz, W. Proper matrix-reinforcement bonding in cast metal matrix composites as a factor of their good quality. Arch. Civil Mech. Eng. 2015, 16, 553-563. [CrossRef]

27. Gawdzińska, K.; Chybowski, L.; Przetakiewicz, W.; Laskowski, R. Application of FMEA in the Quality Estimation of Metal Matrix Composite Castings Produced by Squeeze Infiltration. Arch. Metall. Mater. 2017, 62, 2171-2182. [CrossRef] 